\title{
COMMENTS
}

\section{The Dual Problems of Legal Justification: A Key to the Unity of Karl Llewellyn's Jurisprudence}

In 1960, near the end of his career, Karl Llewellyn summarized the problem of legal justification that he and his fellow realists had created in their writings of the 1930s. He wrote:

[For the realists] an opinion was seen as not at all a reasoned justification: it was instead a "mere rationalization," a term which for fifteen years or more meant (i) false, (ii) tricky and (iii) a cover for the nastiest imaginable hidden motives, with carte blanche to anybody to fill in without evidence. ${ }^{1}$

The result of this account of judicial decision-making, Llewellyn concluded in retrospect, was to lead people to believe that judges "can decide any way they want to, and they do, and then they write it up to suit; [with] the opinion tell[ing] you nothing."2

In what sense can this realist description of judicial decisionmaking be said to create a problem of legal justification? Before answering, it would be best to first define the concept of "legal justification." At least two meanings are possible, and both are implicit in Llewellyn's reference to "justification" in the passage quoted above. The first is non-normative: it relates solely' to the achievement of legal order in decision-making. In this sense of the term, a decision may be called "justified" when it is based on a method that ensures similar resolution of similar cases. ${ }^{3}$ The method's normative content is irrelevant; what matters is the orderliness of outcome-the realists would have said "predictability of outcome" - that a legal system produces. "Justification" refers, in this sense, to the use of any method that brings about regularity of decision-making.

In its first meaning, "justification" refers to the imposition of

' K. Llewellyn, The Common Law Tradition: Deciding Appeals 12 (1960) [hereinafter cited as Common Law Tradition].

${ }^{2}$ Id. at 13 . See also id. at 56.

3 The method may involve a "rule of recognition," see, e.g., H.L.A. HART, The Concept OF LAw 97-107 (1961) (suggesting that a "rule of recognition" confers validity on substantive rules in a legal system); or it may involve an appeal to sociological realities. See, e.g., Pound, The Scope and Purpose of Sociological Jurisprudence (pt. 3), 25 HARv. L. REv. 489, 512-16 (1912). 
order on the positive law. In its second, it refers to right law (ius). ${ }^{4}$ In this normative guise, a theory of legal justification offers a standard for determining whether a legal decision is a just one. A decision may be said to be "justified" in this normative sense when it is ethically correct. A legal system based on a normative theory of "legal justification" might also solve (or partially solve) the problem of legal order, but it need not. No theory of justice rejects legal orderliness as a component of justice, but some theories-intuitionism, for instance, ${ }^{5}$ or natural law ${ }^{6}$-place a higher priority on statements of general principles of ius than they do on specific guidance in making orderly law.

As may be seen from the passage quoted at the outset, Llewellyn's writings about legal justification raised issues of both legal order and ius. Orderliness is imperilled by "trickiness" and "hidden motives": if, as Llewellyn claimed, legal formalism ${ }^{7}$ serves only to obscure "real" judicial intentions, then formalism serves as an unreliable indicator of future decisions. ${ }^{8}$ Similarly, the prospect of just decision-making is also imperilled: to the extent that a formalistic system gives judges leeway for caprice, then to some extent justice is also unlikely to be done.

Llewellyn's achievement, it will be argued in this comment, was to offer a joint resolution of both aspects of the problem of legal justification. He began, as did his fellow realists, by raising explicitly only the problem of legal order-though, as was also the case for the other realists, he posed implicitly the problem of justice from the outset. Llewellyn is best remembered for this phase of his work-best remembered, in fact, for his pessimistic conclusions about the possibility of rule-based predictability in a legal system. ${ }^{9}$

"These concepts are clearly distinct, yet one can find references to "justification" within the context of positive law as well as normative law. Thus John Austin has spoken of justification, within the domain of positive law, by reference to a higher, though still positive, standard. He wrote: "[I]n truth, law itself is the standard of justice. What deviates from any law is unjust with reference to that law, though it may be just with reference to another law of superior authority." See J. Austin, The Province op Jurisprudence Detrermined 190 (H.L.A. Hart ed. 1954).

5 See, e.g., E. Cahn, The Sense of Injustice (1949).

- See, e.g., J. Locke, The Second Treatise of Government 119-39 (1690, T. Peardon ed. 1952).

' See Casebeer, Escape from Liberalism: Fact and Value in Karl Llewellyn, 1977 DukE L.J. 671, 671-72 n.2.

" Predictions of future decisions based on extra-legal factors-such as the judge's economic background-will likely also be unreliable because of the formal constraints on the judge to decide at least some cases in a manner inconsistent with his policy preferences. See text and notes at notes 28-29 infra. See generally text following note 127 infra.

- For an example of Llewellyn's pessimism, see Llewellyn, Some Realism about Realism: Responding to Dean Pound, 44 HaRv. L. REv. 1222, 1241 \& n.47 (1931) [hereinafter cited as 
Although this image of Llewellyn is accurate, it is incomplete. The image misses the unity of Llewellyn's career, for Llewellyn began by creating a problem of legal justification, and he completed his career by solving, in a novel way, the problem he had posed for himself and others. In this sense, his intellectual career had a thematic unity, with legal realist pessimism about predictability in formal systems of jurisprudence yielding to greater optimism when the possibility of predictable law is predicated on the adoption of a theory of justice. The challenge in interpreting Llewellyn's work is to show how the resolution of the problem of normative legal justification also resolves the different legal justification problem he posed in his early career - that of achieving orderly decision-making. Although Llewellyn's resolution of the dual problems of legal justification will be detailed in this comment, it will be helpful at this point to provide an outline of the course he followed.

In his early career, Llewellyn was primarily interested in this question: "How predictable is decision-making via the 'mechanical' approach to legal justification?" His answer, for which he is famous, was "not very." 10 However, in his later career (from about 1940), the focus of Llewellyn's attention changed. Instead of asking about the predictability of one model, he asked, more generally, first, under what conditions is predictable decision-making possible, and second, by what approach should judges made decisions.

The key to Llewellyn's later work, as this comment will show, is that the resolution of the second question also resolves the first. Expressed differently, Llewellyn used a theory of justice as the condition for resolving his problem of legal order. This comment will explore two senses in which he did this. First, there was a "weak" sense in which Llewellyn fused the two aspects of legal justification: he proposed a particular "just" approach to legal decision-making, which he asserted would, if adopted by judges, enhance the predictability of decision-making. Clearly, this was at least Llewellyn's position but the fusion, as stated, leaves open the possibility that other approaches to justice might produce equally predictable

Realism about Realism], reprinted in K. LLEWELLYN, JURISPRUDENCE: REALISM IN THEORY AND Practice 42, 58 (1962) [hereinafter cited as JuRISPRUDENCE]: "[Realist study of the legal system] raises the greatest of doubts as to how far any supposed certainty in decision which may derive merely ... from the presence of accepted rules really goes." An example from contemporary jurisprudence will illustrate the uni-dimensional reputation that Llewellyn now enjoys. H.L.A. Hart cites Llewellyn only as a rule-skeptic and makes no reference to Llewellyn's later, more constructive remarks on rules. See H.L.A. HART, ThE Concept of LAW 1, 120-132, 250 (1961).

${ }^{10}$ See, e.g., Realism about Realism, supra note 9, at 1241, reprinted in JURISPRUDENCE, supra note 9 , at 42,60 . 
decision-making. Second, then, there was a "stronger" fusion impliicit in Llewellyn's writings, one that rejects the possibility that alternative approaches to justice might solve the problem of legal order equally well. According to this view, Llewellyn thought of himself as proposing the approach to justice that most enhances predictability in decision-making. In this sense, the very approach that Llewellyn thought could produce justice was also the one he cited as making legal decision-making as predictable as possible. This latter version of fusion is not inconsistent with the former; but it is present only by implication in Llewellyn's work. Each deserves attention-the first because of its fidelity to Llewellyn's explicit purpose; the second because it clarifies the latent structure of Llewellyn's later jurisprudence.

Both conclusions give unity to Llewellyn's intellectual career. The realist who began by posing chillingly the problem of legal order concluded his career by offering a resolution of the problem of order via a theory of justice. This comment will show, then, how Llewellyn's later work settles the issues imposed in his earlier work.

The comment, it should be added, will attempt no more than this. This will be primarily an interpretation of Llewellyn's work; only secondarily will it offer a critical appraisal of his ideas. There are two reasons for this deliberate limitation of scope. First, Llewellyn is an important, but misunderstood, philosopher of law. Even today, it is widely believed that his writings were solely concerned with descriptive, not prescriptive, jurisprudence. ${ }^{11}$ This misunderstanding must, of course, be resolved before critical appraisal is undertaken. Llewellyn himself is partially responsible for this misunderstanding, for he not only wrote in an infuriatingly elliptical style, but he also-in fighting rearguard actions against those he contemptuously called "high philosophers of law"12 - often claimed misleadingly that he was not writing prescriptive philosophy at all. ${ }^{13}$

" See, e.g., W. Twining, KaRl Llewellyn and the Realist Movement 517-23 (1973); W. Friedman, Legal Theory 200 (3d ed. 1953); Burrus, American Legal Realism, 8 How. L.J. $36,48,50$ (1962). For appraisals of Llewellyn that emphasize his interest in the problem of justice, see E. Garlan, Legal Realism and Justice 103-05 (1941); Casebeer, supra note 7; Jones, Pelagius, 29 U. CHI. L. REv. 619 (1962).

12 See Llewellyn, The Low Philosophy of Law (April 2, 1943) (unpublished essay in Llewellyn papers, University of Chicago Law School, B III 22) [hereinafter cited as Low Philosophy].

is See, for instance, Llewellyn's often-quoted disclaimer in The Common Law Tradition: "What realism was, and is, is a method, nothing more, and the only tenet involved is that the method is a good one." Common Law Tradrion, supra note 1, at 510. See Gilmore, In Memoriam: Karl Llewellyn, 71 YALE L.J. 813, 814 (1962). As the later text will make clear, Llewellyn wished to have the best of both worlds. He wanted, on the one hand, to distinguish himself from "high philosophers of law." But he also wanted to, and often did, make com- 
Second, as an outgrowth of Llewellyn's elliptical style and disclaimers of normative purpose, his prescriptive formulae are hard to define. In fact, it may be impossible to express them rigorously-this comment will show how many of his ideas dissolve into vagueness when pressed beyond a certain point. But at least an attempt at systematic interpretation is needed, and for now criticism will be postponed in favor of understanding.

\section{The Problem of Legal Justification IN Llewellyn's Early WRITINGS}

Among the many polemical points that characterize Llewellyn's early writings, two are particularly significant because they lay a foundation for his later work. The first concerns a new realist approach to defining legal order. The second builds on this, for it applies the definition to show the potential for disorder that was created by the traditional jurisprudence of Llewellyn's day.

Before the realist movement, a well-ordered legal system had been thought of as one that embodied a hierarchy of logically related rules. The orderliness of a system was believed to depend on the completeness and logical rigor of the set of rules employed. ${ }^{14}$ Llewellyn refocused the question of legal order-from the internal order of rules to orderliness in terms of result. ${ }^{15}$ Predictability is, in this sense, a measure of order. Multiple conditions might enhance or reduce the orderliness of results in a legal system; predictability stands as a guide for assessing the degree of order achieved.

Having postulated the predictability standard, Llewellyn then posed the problem of legal order in more starkly negative terms than had any previous philosopher of law. Implicit in even his early work was the general question that he sought to answer in his later writings-under what conditions can legal order (predictability of result) be achieved? But the main thrust of his early writings was directed toward the more limited question of the predictability of results under then-contemporary, rule-based formulae of order. To

ments on justice as it is achieved by a specific, "juristic" method in specific situations. Commentators on Llewellyn have been misled by his public disclaimer in The Common Law Tradition and have ignored his comments, contained in the same book, on the values of justice. Llewellyn's goal was not to define justice (in this sense, his work offered a genuine alternative to the "high philosophy of law") but instead to show the presence of justice "in the daily operations" of the courts (thus a "low philosophy of law"). See, e.g., Common LAw Tradition, supra note 1 , at $51,69-61$.

"See, e.g., Llewellyn, Law and the Modern Mind: A Symposium, 31 CoLum. L. Rev. 82, 82-83 (1931). reprinted in JURISPRUDENCE, supra note 9, at 101, 102-03.

${ }^{15}$ See Realism about Realism, supra note 9 , at 1240-43, reprinted in JURISPRUDENCE, supra note 9 , at 58-62. 
this question his answer was clear: "[T]here is less possibility of accurate prediction of what the courts will do than the traditional rules would lead us to suppose."16

Llewellyn's comments on predictability have been cited so often that they are mentioned here only to illustrate the first phase of his more general concern with the problem of legal order. Llewellyn began negatively. One can of course discern even in his negative comments the basis for more constructive concerns-a concern with legal order as a formal condition of justice, and also a concern with the substantive nature of justice. ${ }^{17}$ But in Llewellyn's early work these are only muted themes. What stands out is his assault on the traditional formulae of legal order. Not until this was completed did Llewellyn turn to the more difficult task of stating "realist" conditions for the achievement of order and justice. ${ }^{18}$

The object of Llewellyn's attacks was the "mechanical jurisprudence" 19 of an older school of philosophers of law. According to the realists, mechanical jurisprudence provided a deductive procedure for justifying the employment of a legal rule. ${ }^{20}$ The mechanical

${ }^{18}$ Realism about Realism, supra note 9 , at 1241, reprinted in JURISPRUDENCE, supra note 9 , at 42,60 .

${ }^{17}$ See id. at 1251 , reprinted in Jurisprudence, supra note 9, at 69 , where Llewellyn discusses the usefulness of his descriptive work for normative theorists: "There are [results]. They are results, primarily on the side of the descriptive sociology discussed thus far. They are big with meaning for attack on the field of Ought-either on what courts ought to do with existing rules, or on what changes in rules are called for."

18 See id. at 1223, JuRisprudence, supra note 9, at 43 . "But there is no reaching a judgment as to whether any specific point of present law does what it ought, until you can first answer what it is doing now."

10 The concept has a peculiar status that must be explained before it is used further. "Mechanical jurisprudence" was not Llewellyn's term; it was Roscoe Pound's. See Pound, Mechanical Jurisprudence, 8 Colum. L. REv. 605 (1908). Furthermore, the idea of "mechanical jurisprudence" was also Pound's, for although philosophers can be found who subscribed to some of its elements, none can be found who subscribed to all. The term is however a valuable index of legal realist belief, for once Pound coined it, the realists used it widely as a catchword for the thought they were rejecting. The term can be used, then, to refer to a catalyst of belief, but not to describe historically existent doctrines. Ronald Dworkin has pointed out that no historical personage can be found who explicitly accepted all the precepts of mechanical jurisprudence. See Dworkin, The Model of Rules, 35 U. CHI. L. REv. 14,16 (1967).

${ }^{20}$ A contrast with Llewellyn's approach will illustrate the significance of the emphasis on deduction. Even in his early career, Llewellyn agreed with traditionalists that a legal decision should be stated in syllogistic form-with a rule employed as major premise, facts as the minor premise, and a conclusion following from these. Dispute centered around the procedure by which a rule was selected and justified. In the 1930 s, Llewellyn had no wellconceived alternative to the mechanical model, but he was at least willing to argue that rules should be justified primarily by reference to the social consequences flowing from their application, not by reference to higher rules from which more subsidiary rules could be deduced. See, e.g., Llewellyn's 1931 claim that the realists share a "conception of law as a means to social ends not as an end in itself." Realism about Realism, supra note 9, at 1236, reprinted 
approach is defined by its use of a hierarchy of logically related principles and rules in deciding cases. Pound, in his description of the system, placed "assumed first principles," rather than rules, at the pinnacle of the hierarchy. ${ }^{21}$ Pound's use of "principle" was deliberate, for he meant to emphasize the ambiguous grounding of orthodox jurisprudence. Such jurisprudence, he suggested, purports to rest solely on generalizations from past cases, but in its appeal to "principles" rather than "rules" the orthodox system implies, without actually claiming, a grounding in "higher," natural, law. ${ }^{22}$ One characteristic of mechanical jurisprudence, then, is its covertly normative status. The other characteristic is its supposedly "gapless" chain of logically related principles and rules. In theory, mechanical jurisprudence is based on a great chain of principles and rules that extend from assumed first principles at its pinnacle to the lowliest sub-rules below. In practice, it was admitted that some rules might not be known-that "gaps" existed in present knowledge, though not in logical reality. Thus a judge employing the mechanical model could use one of two procedures of deductive justification. First, and presumably most often, he could justify the rule he employed by referring to the rule directly higher on the chain and then arguing that this rule entailed the adoption of the rule employed (references that stretched far up the chain would presumably be too cumbersome). Second, whenever a "gap" appeared, he could "discover" a still higher rule and then show how it was entailed by the rule above it. In this way, a judge could enhance the logical rigor of the system by filling in the missing links in the chain..$^{23}$

According to Llewellyn, the mechanical model fails to live up to its own logical pretensions. For this reason, it does not state a sufficient condition for order in a legal system. This criticism must be stated at greater length, and then it will be possible to explain the more general problem of legal justification that emerged from Llewellyn's early jurisprudence.

Llewellyn's criticism was a logical one, a criticism of the "leeway[s] in interpretation of precedent" that are supposedly left

in JURISPRUDENCE, supra note 9, at 42, 55. Llewellyn's procedure was "horizontal"-though it must be emphasized that the details of his procedure had yet to be worked out. By contrast, mechanical jurisprudence employed a "vertical" procedure of rule-selection and justification.

21 Pound, supra note 19 , at 610 .

${ }^{22}$ A student of Pound's, John Dickinson, has described the relation that was assumed to exist between legal principles and higher law. See Dickinson, The Law behind Law, 29 Colum. L. Rev. 285, 307 (1929).

23 See Pound, Juristic Science and the Law, 31 Harv. L. REv. 1047, 1048 (1919). Judge Cardozo rejected this hope for a gapless chain of deductive rules. See B. Cardozo, The NATURE of THE Judicial Process 69-71 (1921). 
exposed by mechanical jurisprudence. ${ }^{24}$ According to Llewellyn, even if a scheme of deductive principles and rules is desirable for the law, such a scheme is in any case unworkable. The basis for this claim is to be found in a distinction between entailment and consistency. Legal rules are so general in scope, Llewellyn argued, that it might be possible to identify a hierarchy of rules that is internally consistent but not one that rests on relations of entailment. Thus two or more rules might be consistent with a higher rule; but in many cases none would be entailed by the higher rule, and none would therefore be logically preferable to its competitor. ${ }^{25}$ The result of this is a "leeway of interpretation of precedent," a point at which rule-based predictability breaks down. The prediction standard makes clear the potential for disorder in the mechanical model. If two or more sub-rules are consistent with a higher one while none is entailed by it, then it would not be possible to predict, on the basis of the rules alone, which would be selected..$^{26}$ One could predict the parameters of selection, but not the precise selection itself. ${ }^{27}$

One consequence of the leeway of precedent which Llewellyn particularly stressed was the opportunity it afforded judges to engage in covert policy making. Since logic is not dispositive, judges are able to promote their own policy preferences under the cover of formalistic rules. Granted, knowledge of these goals might enhance predictability with respect to particular judges. One cannot be optimistic, however, about the possibilities for enhancing predictability by studying the habits and backgrounds of judges. ${ }^{28}$ For one thing, such knowledge is hard to come by: because decision-making is

2t See Realism about Realism, supra note 9, at 1235, reprinted in Jurisprudence, supra note 9 , at 42,71 . Llewellyn later used the more concise phrase "leeways of precedent" in The Common Law Tradition. See Common Law Tradition, supra note 1, at 62-120. Both phrases will be used interchangeably throughout this comment.

${ }^{25}$ Thus, Llewellyn stated that, in many cases, "the authoritative tradition speaks with a forked tongue." Realism about Realism, supra note 9, at 1252, reprinted in JURISPRUDENCE, supra note 9 , at 70.

26. Realism about Realism, supra note 9, at 1239, reprinted in JURISPRUDENCE, supra note 9 , at 42,58 (footnote omitted):

But the line of inquiry via rationalization has come close to demonstrating that in any case doubtful enough to make litigation respectable the available authoritative premises-i.e., premises legitimate and impeccable under the traditional legal techniques-are at least two, and that the two are mutually contradictory as applied to the case in hand. Which opens the question of what made the court select the one available premise rather than the other.

${ }^{27}$ Note that a standard of order based on hindsight might obscure this difficulty, for it is always possible in hindsight to see the consistency of a relation and to overlook the ambiguities that were present when the relation was not one of entailment. In this sense, the prediction standard exposes clearly the difficulties inherent in rule-based jurisprudence.

${ }^{2 \pi}$ See Realism about Realism, supra note 9, at 1242-43, reprinted in JuRISPRUDENCE, supra note 9 , at $42,61-62$. 
formalistic, judges' preferences can be camouflaged in terms that haughtily eschew policy. ${ }^{29}$ And since the goals and quirks will vary greatly from judge to judge, it is unlikely that such study would enhance the predictability of the system as a whole.

What, then, is the problem of legal justification that emerges from the realist critique of mechanical jurisprudence? The problem is primarily one of legal order, for the mechanical model is most clearly deficient in this respect. However, a byproduct of the issue of order is one of justice. Llewellyn was concerned with both, and each issue will be separately considered.

First, the issue of order. If, as Llewellyn claimed, there is under the mechanical model "less possibility of accurate prediction . . . than the traditional rules would lead us to suppose," ${ }^{30}$ what can enhance predictability? Under what conditions can predictability be increased? ? $^{31}$ This was the nagging question never posed in Llewellyn's early jurisprudence and his silence may imply pessimism about its resolution. However, Llewellyn's silence may be considered from two different perspectives. On the one hand, the overt concern of his early writings was the inadequacy of the mechanical model. If he viewed this as his sole purpose, it is not surprising that he attacked orthodox formulae of order and then simply remained silent about the possibility of alternatives. On the other hand, Llewellyn's silence suggested much more. His early work seemed to make unpredictability an inescapable element of judicial decision-making and thus an insuperable hurdle to the achievement of legal order. The assertion that legal order is impossible is admittedly only an implication in Llewellyn's early writings. But the implication is strong, and, when left undenied for a decade, the implication took on an eloquent power of its own. One of Llewellyn's early critics was led to characterize his work as "the jurisprudence of despair,"32 and this view of Llewellyn was widely held. ${ }^{33}$

The impossibility of perfect justice ${ }^{34}$ followed from Llewellyn's

29 Rules could thus serve as "pretty playthings" for the judge. See K. LlewEllyw, ThE Bramble Bush 5 (1930).

30 See Realism about Realism, supra note 9 , at 1241, reprinted in JURISPRUDENCE, supra note 9 , at 60 .

"Llewellyn seems to have very early made the ethical judgment that order is desirable, without intimating the details of the normative framework he was operating within. See Realism about Realism, supra note 9, at 1242, reprinted in JURLSPRUDENCE, supra note 9, at 42,61 , where Llewellyn argues that the realists have in common a goal of controlling unpredictability within a legal system.

${ }^{32}$ Mechem, The Jurisprudence of Despair, 21 Iowa L. Rev. 669 (1936).

${ }^{33}$ See, e.g., Kennedy, A Review of Legal Realism, 9 Ford. L. REv. 362 (1940).

st It should be noted that simply because perfect justice cannot be achieved without order, it cannot be further said that a more orderly system is necessarily more just than a less orderly system. Cf. G. Gilmore, The Ages of American Law 110.11 (1977): 
approach to the question of order. If it is assumed (as it is in most, if not all, theories of justice ${ }^{35}$ ) that a formal condition for the achievement of justice in a legal system is similar judicial treatment of similar cases, ${ }^{36}$ then the mechanical model, by Llewellyn's account, necessarily leads to unjust results within a system. Individual judges might satisfy this formal condition of consistency ${ }^{37}$ but to the extent that judges differ in their choices among the alternative rules presented by the "leeways of precedent," the consequence of using the mechanical model will be systematic injustice to litigants. To put the matter simply, by making order impossible (or at least highly unlikely ${ }^{38}$ ), the leeways of precedent also make the achievement of justice impossible.

The assault on mechanical jurisprudence thus had important implications for the twin issues of legal justification. When he began writing on jurisprudence in the early 1930s, Llewellyn perhaps intended no more than a disrespectful jab at traditionalism. By the latter part of the decade, though, he discovered that his attacks required positive resolution of the issues he had raised. ${ }^{39}$ It was to this resolution that he devoted his later career in jurisprudence.

Law reflects but in no sense determines the moral worth of a society. The values of a reasonably just society will reflect themselves in a reasonably just law. The better the society, the less law there will be. In Heaven there will be no law, and the lion will lie down with the lamb. The values of an unjust society will reflect themselves in an unjust law. The worse the society, the more law there will be. In Hell there will be nothing but law, and due process will be meticulously observed.

${ }_{35}$ The formal requirement of justice is consistency-the treatment of similar cases in a similar way. This formal requirement does not prevent a judge from making distinctions that will influence his decision; the requirement only states that he must apply those distinctions in a consistent way.

36 See note 31 supra.

${ }^{37}$ By deciding all cases coming before them according to the same standards. See text and notes at notes 28-29 supra.

${ }^{3 x}$ It is conceivable, although implausible, that all judges in a system would uniformly choose-from the various alternative resolutions of a case-the same one. In the absence of a uniformly accepted higher principle, this is, of course, unlikely. The leeways of precedent thus are very likely to translate into idiosyncratic results, but need not.

3* In his early writings, Llewellyn gave no indication of how he would solve this problem of formal justice. Indeed, his attack on mechanical jurisprudence was so vehement, there was reason to infer from his silence on the issue that he believed no solution to be possible. However, in The Common Law Tradition, Llewellyn committed himself to a concept of "situation type" and, in so doing, provided a key to the solution of the formal aspect of justice. Judges, Llewellyn argued prescriptively, should "seek and see and weigh first the relevant problem-situations as a type, holding meanwhile so far as may be in suspense [their] reactions to the fireside equities or to other possibly unique attributes of the case in hand." Common LaW Tradition, supra note 1, at 268. To the extent that there are situation types, and to the extent that they are properly identified, then solving the problem of formal justice is facilitated, for like cases may then be treated alike. 


\section{The Change of Focus from Order to Justice in Llewellyn's LATER WRITINGS}

Llewellyn first indicated a change of direction in his thinking in a 1940 survey of the course of legal realism during the previous decade. The concept of justice, he admitted, had been-largely missing from his early work, which had instead focused on nonnormative issues (stressing particularly the lack of order achievable by mechanical jurisprudence). By 1940, though, he was willing to reject the tenor, though not the entire content, of his earlier work. Llewellyn's statement was framed as an apology to Dean Pound, who had done so much to spur legal realism but who had never subscribed to its more vehement attacks on mechanical jurisprudence. Llewellyn said:

[I]f these modern jurisprudes are forgetting that the goal of law is justice, and forgetting also that judges and other officials must not be free to be arbitrary, then they need correction at once and, if need be, with a club. For to Pound, the heart and core of Jurisprudence is what the heart and core of Jurisprudence ought to be to any scholar: to wit, right guidance to the judge-or to the legislator-or to the administrator. And I for one am ready to do open penance for any part I may have played in giving occasion for the feeling that modern jurisprudes or any of them had ever lost sight of this. ${ }^{40}$

This statement signals a shift of attention to an attempt to give normative directives to judicial decision-makers. Although the substance of the "right guidance" that Llewellyn would henceforth provide to judges was, as of this point in Llewellyn's career, ambiguous, this section will try to show the "right guidance" Llewellyn eventually arrived at. The next section will try to show that this "right guidance" also served to resolve the problem of order posed in his earlier writings. This section and the next will show, in other words, that Llewellyn proposed intersecting answers to the two questions of legal justification: (1) By what standard is a just decision made? (2) Under what conditions can legal order be obtained?

\section{A. The Conceptual Bases of Llewellyn's Later Thought}

Perhaps the greatest barrier to the understanding of Llewellyn's later work lies in the special set of concepts that express his ideas.

s0 Llewellyn, On Reading and Using the Newer Jurisprudence, 40 CoLUM. L. REv. 581, $603(1940)$ [hereinafter cited as Newer Jurisprudence], reprinted in JURISPRuDENCE, supra note 9 , at 128, 152-53 (footnote omitted, emphasis added). 
Philosophers of law have had no difficulty with his early work, for there his chief concern was with the criticism of rule-based jurisprudence, and the theory of rules has long been the stock in trade in philosophy of law. In his later writings, though, as he sought alternatives to rule-based models of order, Llewellyn branched out to fields that were foreign to philosophers of law and that consequently created a basis for misunderstanding. ${ }^{11}$ The special assumptions of Llewellyn's later work must therefore be explained before his solutions are reviewed.

Three concepts must be explicated: "probable permanent values for man," "juristic method," and "sociological function." These concepts will be considered in terms of their meaning in the Llewellyn lexicon and also in terms of their intellectual parentage at the time Llewellyn adopted them.

1. "Probable Permanent Values." Llewellyn concluded, sometime during the late 1930s, that there are "certain probable permanent values for Man" that establish minimal standards for just action. ${ }^{42}$ Llewellyn's claim was an axiological one, and it straddled the fence between description and prescription. The claim could be seen as-and Llewellyn claimed that it in fact was-the result of empirical work in cultural anthropology..$^{43}$ However, it contained strong normative overtones as well, for although there may be no logical link between the existence of supposedly universal values and an ethical imperative to promote those values, the psychological linkage is strong indeed.

2. "The Supremacy of Method." 4 Ironically, Llewellyn's discussion of "probable permanent values" committed him to just the kind of "eternal principle" he had deplored in mechanical jurisprudence. However, Llewellyn believed these permanent values to be concerned only with "basic needs" and not with advanced, and to his mind, variable needs. ${ }^{45}$ In this respect, Llewellyn imposed at

"Not all Llewellyn commentators have overlooked the sociological foundations of his work. See, e.g., W. Twining, supra note 11, at 168-69; Hoebel, Karl Llewellyn: Anthropological Jurisprude, 18 RutGens L. REv. 735 (1964).

${ }^{12}$ Llewellyn, The Theory of Legal "Science," 20 N.C.L. REv. 1, 23 n.27 (1941) [hereinafter cited as Legal Science].

is Id.

" This is the title of chapter 9 of J. Dewey, The Quest for CERTaINTY (1929).

45 Two chains of reasoning must be traced in Llewellyn's writings of 1940-1942, writings that, by outlining his functionalist approach to the sociology of law, set the stage for the remaining work of his career. First, the linkage of "probable permanent values" with "basic needs." Here, one should note that Llewellyn's reference to these values in Legal Science, supra note 42 , at $23 \mathrm{n} .27$, is followed by a citation to his essay, Llewellyn, On the Good, the True, the Beautiful in Law, 9 U. CH. L. REv. 224, 250 (1942) [hereinafter cited as Good in Law], reprinted in JURISPRUDENCE, supra note 9, at 167, $167 \mathrm{n}$. $\dagger$, which acknowledges his essay 
least one "eternal" condition on the doing of justice: fulfill "basic needs" before other needs. Beyond this point, ${ }^{46}$ though, he rejected the possibility of specifying the content of needs to be fulfilled. As will be described further, juristic method-a method that could identify ethically relevant needs, weigh them against others, and then resolve possible tensions between them-would, he believed, have to take the place of specific norms of conduct. "First principles" were therefore discarded-or, it seemed, all but one was. ${ }^{47}$ The deductive approach to the selection of legal rules by reference to first principles was therefore discarded. And in place of these, Llewellyn proposed to install a method that would allow for the selection of rules appropriate for different cultural contexts.

The basis for this radical proposal needs to be explained. Latent in Llewellyn's work is the premise (more fully expressed by John Dewey, whom Llewellyn greatly admired ${ }^{48}$ ) that ethical think-

on Legal Science as a "companion piece." The essay On the Good, the True, the Beautiful in Law classifies the satisfaction of "basic needs" as a good, for it states that "these basic bare-bones needs must be met, before we can get on at all into any other aspects of the Good, for law." See id. at 253, JuRISPRUDENCE, supra note 9, at 200. Thus, on the basis of these crosscitations, one must assume that the good of meeting "basic needs" is one of the "probable permanent values" alluded to in Legal Science, supra note 42 , at 23 n.27.

A second, and parallel, chain of reasoning must be followed from "probable permanent values" to the surplus, "questing" needs of a society. The same cross-references cited above can be employed here. In this case, though, Llewellyn defined "questing for the Good" in contentless terms. He spoke, for instance, of points of "grace" and "beauty" that are characteristic of law that fulfills surplus needs. And he also spoke of a "Good for society" that can be reached only when basic needs have been met. See Good in Law, supra at 25354, reprinted in JURISPRUDENCE, supra note 9 , at 167, 200-01. In both cases, the specific content of "the Good" has been left undefined, and Llewellyn no doubt believed that this varied from society to society. Thus the linkage of "probable permanent values" and "questing for the Good" is as follows: the latter is such a value, but, unlike basic needs, the conditions for its satisfaction vary from society to society.

"Llewellyn has, to this extent, rejected a wholly contentless approach to juristic method, for he has stated that basic needs "must be met" before moving on to any other aspect of the "Good, for law." See note 45 supra. The qualification is highiy significant in light of the claim that Llewellyn made, in following Dewey, that "realism is a method, and nothing more .... [It] includes nothing about whither to go." Common LAw TRADrTion, supra note 1 , at 510 . See note 52 infra. In the case of basic needs, though, Llewellyn assigned an ethical task for juristic method, for he required that these be satisfied before moving on to others. See text and notes at notes $89-95$ infra.

${ }^{17}$ The one principle that remained was the requirement that basic needs be satisfied before surplus ones. See note 46 supra.

${ }^{18}$ In an unpublished tribute to Dewey, which Llewellyn submitted to The New Republic in 1949 for a celebration of the philosopher's ninetieth birthday, Llewellyn hailed him as a "true prophet" of twentieth-century America who had "felt and then voiced surely what was the nation's need." Llewellyn, John Dewey and Our Law, (1949) (unpublished essay in Llewellyn papers, University of Chicago Law School, B III 14). Given the crucial importance of the concept of "need" in Llewellyn's thought, this was the highest praise he could bestow on any man. Llewellyn's biographer has also remarked, on the basis of personal contact with 
ing must be reoriented from a concern with formal statements of principle to a focus on specific contexts of conduct. This belief underlaid Llewellyn's criticism of mechanical jurisprudence, a criticism Dewey shared with Llewellyn. ${ }^{49}$ And it also formed the basis for the positive commitment ${ }^{50}$ that Llewellyn made to the "supremacy of method" (Dewey's term) as the appropriate way to guide jurisprudence between the Scylla of formalism and the Charybdis of nihilism. Dewey argued that " $[t]$ he theory of fixed ends inevitably leads thought into the bog of disputes that cannot be settled." 51 Dewey's remedy was to substitute "method" for first principles-a proposal as problematic as it is significant. Dewey stated: "The need in morals is for specific methods of inquiry and contrivance: Methods of inquiry to locate difficulties and evils; methods of contrivance to form plans to be used as working hypotheses in dealing with them." 52 Llewellyn's later writings work out

Llewellyn, that "[t]he most pleasing compliment that could be paid to Llewellyn was to compare him with John Dewey." W. Twining, supra note 11, at 423.

"Dewey contributed to the attack on mechanical jurisprudence in Dewey, Logical Method and Law, 10 CORNELL L.Q. 17 (1924).

${ }^{\text {so }}$ But see note 52 infra.

31 J. Dewey, Reconstruction in Philosophy 166 (1920).

32 Id. at 170 . This passage seems to be a forerunner of Llewellyn's disclaimer of substantive normative intent, written forty years later in The Common Law Tradition. "What realism was, and is, is a method, nothing more .... TT/he method includes nothing at all about whither to go .... Realism is not a philosophy, but a technology." Common LAw Tradition, supra note 1 , at 510. In passages such as these, Dewey and Llewellyn suggest that their methods are neutral as to content-that they can be applied to any situation, no matter what substantive goal the user of the method may have. However, Dewey and Llewellyn themselves employ their methods for one type of substantive ethical concern (promoting the needs of the Entirety, an ambiguous, but not wholly contentless, term, see text and notes at notes $93-95$ infra), and strongly suggest that their methods would not be appropriate for any other kind of concern. For Llewellyn on this, see his distinction between legal and juristic method, quoted in text at note 100 infra. For Dewey's conception of substantive ethical purpose, see J. Dewey, Reconstruction in Philosophy 186 (1920).

How, then, are we to explain the tension between ostensibly value-neutral "method" and the need-based application of it? One could accuse Dewey and Llewellyn (and Ruth Benedict, as well, whose concept of "cultural configuration" Llewellyn employed in his studies of the Cheyennes, see note 93 infra) of wanting the best of both worlds-of rejecting the principles of liberalism based on natural right, and so espousing "method" as an alternative, while also insisting on the application of that method for purposes consistent with liberalism. Unfortunately, this accusation has some merit, for Dewey's and Llewellyn's definitions of method allow for applications that they would not have approved of. However, there is also much to be praised in this attempt by a "Columbia school" (of which Dewey was the head, and Llewellyn and Benedict, among others, his pupils) to face up to the diversity of cultures. On the one hand, these members of the school attempted to escape the straitjacket of eighteenth century liberalism and to accept cultures on their own terms. On the other hand, they also sought to preserve the liberal virtues of tolerance and concern for individual welfare. Appreciation of diverse cultures can, however, lead to complete ethical relativism when pressed to its logical conclusion, thus making even tolerance and concern for individual welfare values that are contingent for a particular culture. Members of the Columbia school 
the jurisprudential implications of this proposal for "ethical method." In fact, just as Llewellyn's early writings stridently reject the mechanical "quest for [legal] certainty," his later work can best be understood as giving jurisprudential expression to the strengths-and ambiguities-of Dewey's "reconstruction in philosophy."

Dewey's method was primarily motivated by ethical considerations. Llewellyn's was grounded in dual concerns-to solve problems of order and problems of justice. In approaching the former issue, Llewellyn claimed to have discovered judicial craft traditions, which he variously called "juristic method," 53 "craft," "grand style," 55 which supposedly guarantee regularity of decisionmaking. Method served, in this sense, as an antidote to the indeterminacy inherent in deductive systems of principles and rules. A judge could not look to first principles or rules for firm guidance; according to Llewellyn, the "leeways of precedent" left huge discretionary gaps in the selection of a rule appropriate for a case. However, a judge could look to the craft-traditions of his profession, and here he could find what Llewellyn called a "diagnostic method" that was supposed to provide for more definite results. ${ }^{56}$ Rules were not totally discarded as a means to legal order; Llewellyn still granted them a significant place in his jurisprudence. ${ }^{57}$ But when considered from the standpoint of the observer wishing for predictability of outcome, or from the standpoint of the judge wishing definite guidance, the legal rule was, according to Llewellyn, a tool

overlooked this inner tension; and their work therefore reflects the tension without resolving it. They can be faulted for failing to acknowledge the tension but not for creating it, for the tension is central to the dilemmas of twentieth, as distinct from eighteenth, century liberalism.

ss Llewellyn introduced the concept of juristic method in The Normative, The Legal, and The Law-Jobs: The Problem of Juristic Method, 49 YaLE L.J. 1355 (1940) [hereinafter cited as The Normative]. He then developed it further in part 3 of The Cheyenne Way. A. HoEBEL \& K. Llewellyn, The Cheyenne Way 273-340 (1941) [hereinafter cited as Cheyenne Way].

st "Craft" is the connective concept between Llewellyn's work on the Cheyenne and common law. In a 1949 essay, Llewellyn substituted the term "craft" for "juristic method" but then described the role of judicial craft in terms of the same "law-jobs" he had outlined in his writings of 1940-1941. See Llewellyn, Law and the Social Sciences-Especially Sociology, 62 Harv. L. Rev. 1286, 1293, 1303-05 (1949) [hereinafter cited as Law \& Social Sciences], reprinted in JURISPRUDENCE, supra note 9, at 352, 359, 369-71.

${ }^{35}$ The "grand style" is the special style of the great common law judges who employed juristic method. See Common LaW Tradition, supra note 1, at 62-71.

58 Llewellyn argued that correct "diagnosis" of "situation-type" was the key to good judging. See id. at 324 .

${ }^{57}$ Thus Llewellyn stated that "A rule which wears both a right situation-reason and a clear scope-criterion on its face yields regularity, reckonability, and justice all together. We may add that such a rule is a staff and a comfort to any court, as well as to any counselor." See Common Law Tradition, supra note 1, at 183. 
that offered only limited help. In a craft tradition, "method" would take precedence over rules; for all hard cases, prediction would have to rest on a knowledge of how method, not rules, is applied.

It is at the normative level that the concept of method is most problematic. How, one wants to know, can a method that operates apart from fixed principles nonetheless provide guidance about desirable conduct? Llewellyn often implied that this was possible..$^{58}$ Indeed, his attack on "eternal principles" lurking behind mechanical jurisprudence made it tactically necessary for him to depict his thought as free from such ethical ghosts. If it in fact were-if Llewellyn's method had been able to provide "right guidance" without ever having committed himself to an ethical principle-then it would deserve attention as a major breakthrough in ethical analysis. However, as will be shown shortly, Llewellyn wanted the best of both worlds. On the one hand, he wanted to reject the "eternal principle" approach of older jurisprudence-thus the need to substitute method for fixed principles. On the other hand, though, his interest was in a method of justice, so he implicitly linked his method to a normative premise derived from sociological functionalism. His method in fact never stood alone, and attention now must be turned again to its silent ethical premise.

3. Sociological Functionalism. An important aspect of Llewellyn's jurisprudence-and, in fact, an important aspect of the jurisprudence of the entire legal realist movement ${ }^{59}$-is a commitment

s" Llewellyn often spoke of "horse-sense" as the connective link between juristic method and proper judicial action. See, in this regard, his revealing remarks on how a "low philosophy of law" could replace high philosophy's emphasis on the "Whitherness of the Whatever... and the Whatever's Whetherness." Low Philosophy, supra note 12, at B III 22. "Horse-sense" operates, in this respect, as a kind of ethical intuition that guides juristic method. In his desire to disassociate himself from "high philosophical" concerns, Llewellyn may have succeeded at times in convincing himself that he did not offer a prescriptive theory of justice. On other occasions, though, he spoke directly of the just solutions that are created by the application of juristic method. On these occasions, he was clearly offering a sociologically functionalist account of "justice." For examples of these, see CheYEnne WAY, supra note 53, at 309; Common Law Tradition, supra note 1, at 59-61, 513.

59 The precursors of legal realism and the realists themselves were heavily indebted to sociological functionalism. See generally G. CASPER, JURISTISCHER REALISMUS UND POLITISChE ThEORIE IM AMERIKANISCHEN RECHTSDENKEN 27-42 (1967). Among the precursors of realism, one can cite Roscoe Pound, who argued in 1919 that "[p]erhaps the most significant advance in the modern science of law is the change from the analytical to the functional attitude." Pound, The Administrative Application of Legal Standards, in REPORT OF THE FORTY-SECOND annual Meeting of the American Bar Association 445, 449 (1919). See also B. Cardozo, supra note 23 , at 112 , where it is argued that the highest criterion of judicial decision-making should be sociological functionalism. The functionalist perspective of the realists themselves is best expressed by Walter Wheeler Cook's prospectus for the John Hopkins Institute for the Study of Law. After comparing the Institute's goals with those of Hopkins' Medical School, Cook asked, "If we substitute 'social maladjustment' for 'disease' . . . could the Institute ... 
to the functionalist analysis of the relation of law to social structure. Law, the realists argued, exists as a socially integrative device that can meet the "needs" of the community it serves, and law in its mechanical state can often suffer from what William F. Ogburn called "cultural lag":

The thesis [of cultural lag] is that the various parts of modern culture are not changing at the same rate, some parts are changing much more rapidly than others; and that since there is a correlation and interdependence of parts, a rapid change in one part of culture requires readjustments through other changes in the various correlated parts of culture..$^{60}$

The theme of cultural lag was a constant one in Llewellyn's jurisprudence, but it was applied differently in the early and later writings. At first, it served as the cutting edge of criticism, with the concept used as a device that exposed the artificial quality of mechanical jurisprudence. Later, though, the concept of "cultural lag"- -and the functionalist theory on which it was based-provided the sociological preconditions for both Llewellyn's theories of legal order and justice. A brief outline of how this was done is needed.

As a key to the problem of legal order, functionalism complemented Llewellyn's theory of juristic method. The judges Llewellyn admired were armed with the craft traditions (juristic method) of their guild, and these traditions in turn had grown out of the expec-

ask for any better formula [defining its goals]?" The Johns Hopkins UnIVERISTY CIRcular: The Institute for the Study of LAW 14 (1929), as quoted in W. Rumble, AMERICAN Legal Realism: The REalist Movement 18 (1968).

so W. Ogburn, Soctal Change 200-01 (1922).

On only one ocasion did Llewellyn cite Ogburn directly, see Llewellyn, Behind the Law of Divorce (pt. 1), 32 Colum. L. Rev. 1281 n.*(1932) (citing W. OgBurN, AMERICAN Marriage and Family Relationships (1928)), and there is no reason to believe that he was heavily indebted to Ogburn. Yet it is clear that Ogburn, a contemporary of the realists and also a colleague of Llewellyn's at Columbia and Chicago, gave general expression to the vision that realists shared of the relation of law to society. Compare the statement of Ogburn quoted in the text with these statements by Llewellyn: First, from an article of 1931: "[The realists share the] conception of society in flux, and in flux typically faster than the law, so that the probability is always given that any portion of law needs reexamination to determine how far it fits the society it purports to serve." Some Realism about Realism, supra note 9, at 1236, reprinted in JURISPRUDENCE, supra note 9, at 42, 55 .

And from an unpublished speech on American legal history, where at the point quoted, he was trying to explain the flaws of late nineteenth century judges:

Law lagging, but struggling still: . . . it served not even Industry, it served particular industries, or particular outfits within an industry, and served these one by one .... American law, through all of this, vegetated or worse, while men and the country lived.

American law consumed its past, and gave a mortgage on its future.

Law and Leadership, undated manuscript placed about 1942, Llewellyn Papers, University of Chicago Law School B III 19, at 53-54. 
tations and the functional needs of the societies they served. An image of judicial "doctor" and social "patient" was central to Llewellyn's descriptive jurisprudence. In drawing on functionalism, Llewellyn conceived of society in teleological terms, with each part having a potential role to play in the maintenance of the overall equilibrium of needs. The judge was, in this sense, the "surgeon" of society. In an important passage in The Common Law Tradition, Llewellyn likened judicial methods of decision-making to those of surgery. First, he said, comes "the effort to diagnose the significant problem involved, and ... the effort to mark out the life-situation which gives rise to the problem." "determine ... the most appropriate line of treatment and [make] the specific prescription which may be called for." 62 Both "diagnosis" and "prescription" are a part of the juristic method. To Llewellyn the functionalist, then, a judge is expected by society to pay attention to "the health of the whole," overall equilibrium is to be maintained.

Llewellyn's normative thesis flowed psychologically, though not logically, from his functionalist description of the role of judges within society. In addition to his obvious approval of socially integrated societies, ${ }^{64}$ Llewellyn on occasion went further than mere description and argued that the judge should correct cultural lag by using the law as a means of guaranteeing the functional harmony of society's parts. ${ }^{65}$ An implicit transition was made from descrip-

" Common Law Tradition, supra note 1 , at 450 . In this respect, judicial diagnosis was addressed not merely to the situation at hand but also to a more general "situation type." The accurate identification of a "situation type"-that is, the identification of its general rather than incidental features-greatly facilitates fulfillment of a formal condition of justice, that of consistency of result in similar cases. The accurate classification of cases makes it easier for judges to treat similar situations in the same way on future occasions.

"2 Common Law Tradition, supra note 1, at 450 (emphasis deleted). This passage contains Llewellyn's clearest statement of the distinction between diagnosis and prescription, both of which are components of juristic method. Ironically, Llewellyn warns here against blurring these two features, yet he was often prone to do just this. See text and notes at notes 113-114 infra for a discussion of the way in which he blurred the distinction.

"3 Cheyenne Way, supra note 53, at 332 .

" Llewellyn's positive valuation of social health is unmistakable throughout his later writings. In 1941, for instance, Llewellyn identified the "health of the whole" with the "social aspect of 'Justice.' " See ChEYENNE WAY, supra note 53, at 332. Furthermore, he also framed the major theme of his later jurisprudence in terms of health when he stated that the "opposition or contrast of 'law' and 'justice' is unhealthy." Id. at 333. In The Common Law Tradition, Llewellyn developed his medical imagery further and included references to "diagnosis" and "prescription." See notes and text at notes 61-62 supra. Thus he praised Cardozo for his skill as a diagnostician. See Common Law Tradition, supra note 1, at 431. And Llewellyn also stated that "rightly diagnosed types of problem-situation[s] [are] the key to good law and good judging." Id. at 324.

is The proof for this proposition is to be found in a speech that Llewellyn made to the 
tion of "social health" to a prescription for its maintenance. ${ }^{66} \mathrm{Llew}$ ellyn's advocacy of the use of juristic method went beyond a mere description of the diagnostic technique needed if social maladjustments are to be corrected; it was based on an ethical view that it is

Conference of Chief Justices in 1959. First, a basic premise must be stated: Llewellyn identified the "grand style" and its cognate terms, "craft" and "juristic method," as the techniques that are designed to bring about social health. Thus he defined juristic method as the technique that can keep "law abreast of the needs of the Entirety." See Cheyenne Way, supra note 53 at 309 . And on another occasion, he described how the craft of law can offer a "planned cure" for its society. See Law \& Social Sciences, supra note 54, at 1293, reprinted in JURISPRUDENCE, supra note 9, at 358. By themselves, these do not indicate that Llewellyn believed such cures to be desirable-only that craft, method, and so forth, can effect cures. However, in the speech before the Chief Justices, Llewellyn clearly advocated judicial adoption of the grand style. In his introductory remarks on the speech in The Common Law Tradition, Llewellyn stated that "This [emphasis on the grand style] ought, I am urging, to become the procedure not merely 'more often than not,' but regularly." Then, in his speech, he stated, "In the net: as in the Grand Tradition, so it is largely in current practice, and even more in current need; but while the recapture of the Grand Tradition is almost there, it is irritatingly not yet there, quite. It needs to be fulfilled." Common Law TradrTon, supra note 1, at 378-79 (emphasis added). It should also be noted that, in 1951, in an afterword to a new edition of The Bramble Bush, Llewellyn stated that "It seems to me essential to health of our law and legal work that student, bar and bench should know that the Grand Tradition of the Common Law is our rightful heritage and needs complete and conscious recapture." See K. Llewellyn, The Bramble Bush 157 (2d ed. 1951). Since the grand style is the means of bringing about social health, and since Llewellyn advocated its adoption, he also advocated the principle, "heal the body politic."

${ }^{66}$ In 1931, Llewellyn stated that legal realists had imposed on themselves a "temporary divorce of Is and Ought for purposes of study." See Realism about Realism, supra note 9, at 1236, reprinted in JuRisprudencE, supra note 9, at 55 . Thus Llewellyn rejected, at least temporarily, the employment of descriptive terms for the sake of making prescriptions and also rejected temporarily the enterprise of normative jurisprudence. Llewellyn never stated explicitly that the divorce had been terminated. However, there are a number of indications that the termination came in the early 1940s. It was in 1940 that Llewellyn offered "public penance" to Pound and stated that henceforth he would recognize "right guidance to the judge" as "the heart and core of jurisprudence." See text and note at note 40 supra. Furthermore, in 1941, Llewellyn also claimed that he had discovered what he called "probable permanent values for Man." See text and notes at notes 42-43 supra.

How exactly, though, did Llewellyn terminate his self-imposed divorce? In The Common Law Tradition, Llewellyn stated that "I have found it not only difficult but unwise to keep description unmixed with my value-judgments and desires." Common LaW Tradition, supra note 1 , at 51 . His blending of fact and value is best understood in the context of his medical imagery. For Llewellyn, "health" was a term that straddled the fence between "Is" and "Ought." There are only a few occasions when he stated that social health ought to be promoted. See note 64 supra. However, there were many occasions when Llewellyn used value-laden terminology (such as "heal" and "cure") to describe the achievement of social "health." See note 64 supra. Logically, one can describe the prerequisities for "social health" without prescribing its maintenance as a social good. Psychologically, though, it is difficult to separate description and prescription in this case. As notes 64 and 65 demonstrate, Llewellyn generally confined himself to enthusiastic description, though he occasionally crossed the logical boundary to make an explicit prescription.

It should also be noted that Ogburn, who was also a sociological functionalist, was less reluctant to cross this line. He stated that it is "desirable" to cure social "maladjustment." See W. OGBURN, supra note 60, at 201. 
desirable to effect a cure for social "maladjustments." Juristic method thus does not appear to be ethically neutral. ${ }^{67}$ Instead, it provides the means by which Llewellyn's normative premise that the body politic ought to be healed may be implemented. ${ }^{68}$ Juristic method functions as the means of fulfilling his normative end.

\section{B. Llewellyn's Discovery}

One more preliminary issue must be raised before Llewellyn's theories of legal justification can be subjected to more careful scrutiny. This issue centers around the causes of Llewellyn's change of direction. Why did Llewellyn change direction at all? Why, in other words, did he, in his later career, wish to offer "right guidance" when he had initially set out only to question the mechanical model of jurisprudence?

The immediate cause of Llewellyn's change is to be found in the experience he had in the late 1930s in studying the law of the Cheyenne Indians. As often happens in anthropological fieldwork, it took the investigation of another society to awaken Llewellyn to the potential of his own. In the summer of 1935, Llewellyn and Adamson Hoebel, an anthropologist who had worked with him at Columbia University, travelled to Montana to observe the operation of the Cheyenne legal system. From an anthropological standpoint, there was much that was questionable about the conclusions Llewellyn reached: he made no observations of his own (his cases were based on tribesmen's recollections of past events $\left.{ }^{69}\right)$, he did little fieldwork: (this was left to Hoebel ${ }^{70}$ ), and he may not have known enough about Cheyenne society to have been able to reach sound conclusions about the relations of its legal and social institutions. ${ }^{71}$ Nevertheless, from a jurisprudential standpoint, his conclusions were of major importance. Twenty-five years after the expedition, Llewel-

"Juristic method also served as a means by which Llewellyn could minimize the content of his definition of justice. The sole restriction that Llewellyn imposed on the achievement of justice was that basic needs "must be met" before surplus ones can legitimately be considered. See note and text at note 45 supra. Beyond this point, though, juristic method was assigned the task of detecting the needs relevant for the just solution of a situation, of ordering them, and of prescribing a cure for the situation. See text and notes at notes 61-62 supra for Llewellyn's description of the techniques of diagnosis and prescription.

" Llewellyn stated that juristic method "is the problem and technique of solution, for the Entirety ...." See CHEYENnE WaY, supra note 53, at 309.

" Cheyenne Way, supra note 53, at 29-32.

70 W. Twining, supra note 11, at 155.

"This is not to say that the The Cheyenne Way was not a work of major anthropological importance. Llewellyn's biographer points out that in fact "the book made a much greater impression upon anthropologists than upon jurists." W. TwiNING, supra note 11, at 166. 
lyn defined the significance of his experience among the Cheyennes in the following way: "The law of the Cheyenne Indians made clear to me what I had never before dreamed: to wit, that law and justice had no need at all to be in conflict or even in too much tension, but could instead represent a daily working harmony."72

Llewellyn believed, then, that he had discovered a society that had solved the twin aspects of his problem of legal justification. His early work, he admitted, had been based on the assumption that this was impossible-that legal order could be achieved only at the expense of justice. As he remarked:

[I]n common ... . with most jurisprudes, I had [before the trip to the Cheyennes] mostly taken for granted a sort of perpetual struggle between the needs of regularity and form and of the precedent phase of justice on the one side and, on the other, any dynamic readjustment of a going system to just what needed to be done. ${ }^{73}$

Now, with the discovery of the Cheyennes, ${ }^{74}$ Llewellyn was convinced that legal order (and the formal conditions of justice) could be brought into a "daily working harmony" with the substantive conditions of justice, that is, the satisfaction of individual and social need. The discovery was to be central for all of Llewellyn's remaining work in jurisprudence. The Cheyennes provided him with a model of successful anti-formalism; and Llewellyn acknowledged that their model would have general relevance for his own, as well as primitive, legal systems: "You suddenly hit upon beauty and vision in a strange culture, and you may be the person in whom a seed takes root, so that light is shed at home."75

Having discovered this solution among the Cheyennes, the challenge that Llewellyn faced was to generalize from the characteristics of the unmechanical approach that he found among them. This challenge had two dimensions: first, Llewellyn had to show that the structure of a primitive legal system carried important implications for a complex system; second, Llewellyn had to show

72 Common Law Tradition, supra note 1, at 513.

Id.

7 Llewellyn's remarks in The Common Law Tradition-his references to what he had "never before dreamed," $i d$., and to how he had previously taken for granted a struggle for formal and substantive justice-indicate the fortuitousness of his discovery. It is possible that before embarking on his trip to Montana, Llewellyn had hoped vaguely to find an alternative to mechanical jurisprudence. See, in this regard, Hoebel, supra note 41 , at 735-36 for an account of their conversations prior to the trip. However, Llewellyn's recollections in The Common Law Tradition reveal the surprise he felt on actually making the discovery.

${ }^{75}$ Common Law Tradition, supra note 1, at 513 n.12. 
how anti-formalism could be applied in practice. In regard to the first, it is interesting to note that many of the concepts that Llewellyn developed from studying Cheyenne law he carried over into his work on the common law. In this sense, the Cheyenne trip enabled Llewellyn to "illuminat[e] . . . modern law by [turning to] a primitive problem." ${ }^{\prime 6}$ Consider how the concepts that have already been outlined were carried over from The Cheyenne Way to The Common Law Tradition. (1) In 1940-1941, in The Cheyenne Way, Llewellyn first proposed his theory of "probable permanent values" and "basic needs." "T The theory was particularly appropriate for underdeveloped societies but seemingly less so for developed ones. Nonetheless, Llewellyn adhered to this theory in his later writings (in which his chief concern was English and American common law), using throughout a "need" approach to legal justification. ${ }^{78}$ (2) Llewellyn's search for a model of juristic method was first satisfied among the Cheyennes-a people, as he put it, of "utterly clean juristic intuition." ${ }^{\prime 9}$ It was on the basis of this that Llewellyn first

is Cheyenne Way, supra note 53 , at 44.

$\pi$ See note 45 supra for an account of the relation between these two concepts.

${ }^{7 x}$ If, as this essay argues, "need" is the axial concept of Llewellyn's post-1940 jurisprudence, then the theory of situational "immanence" that Llewellyn took from Levin Goldschmidt's writings must be subordinate to the "need" approach to justice. It in fact is. Llewellyn's discussions of immanence show that his primary concern was the discernment of the "life-needs" that supposedly are "immanent" in a situation. See Common Law TradlTION, supra note 1, at 127. The celebrated Goldschmidt quotation in The Common Law Tradition, Common Law Tradition, supra note 1, at 122 (quoting Goldschmidt, Preface to Kritik des ENTwURfs eines Handelgezetzbuchs, 4 KRIT. Zeitschr. F. D. Ges. RechiswisSENSCHAFT no. 4), is, in this respect, no more than an affirmation of both the objectivity of social need and the judge's duty to cope with such needs, a point Llewellyn had been making since the publication of The Cheyenne Way. Commentators who have taken Goldschmidt's concept of "immanence" as their point of departure have therefore exposed themselves to two interpretative difficulties. First, the Goldschmidt passage has led them to overlook the degree to which situational "immanence" adds only a metaphysical gloss to the functionalist approach Llewellyn had championed since 1940 . Second, the pasage has led them into a difficulty that was also present in Llewellyn's own writings. Llewellyn himself emphasized the importance of distinguishing between diagnosis of the needs in a situation and prescription for their cure. See Common LAW Tradition, supra note 1, at 450 and text and notes at notes 113-114 infra. On some occasions, Llewellyn honored his own advice and emphasized the extent to which just rules are constructed out of, and are not immanent in, a given situation. See, for instance, Common Law Tradimon, supra note 1, at 142, where Llewellyn describes how judges can improve on rules; and see also id. at 331, where Llewellyn praises creative judicial action in transforming a situation. On other occasions, though, Llewellyn's emphasis on immanence allowed him to blur the line between diagnosis and prescription - to write, as Goldschmidt did, as if right law were "indwelling in the very circumstances of life." Id. at 122. These are occasions on which Llewellyn violated the distinction he set for himself. Id. at 450. For commentators who have taken the Goldschmidt passage as a key to Llewellyn's later work, see W. Twining, supra note 11, at 217-227; Clark \& Trubek, The Creative Role of the Judge: Restraint and Freedom in The Common Law Tradition, 71 YaLE L.J. 255 (1961).

7 CheYENnE WAY, supra note 53, at 313. 
outlined, in 1940-1941, a theory of jural craft that dispensed with the mechanical approach to rules and replaced it with the authority of craft guidance. ${ }^{80}$ Indeed, one can go even further than this: the Cheyennes seemed to Llewellyn to represent tangible proof of the extent to which a society can dispense with deductive approaches to justification while producing ethically correct and largely selfconsistent judicial decisions. The "proof" for this claim may well be impossible to obtain (and the claim itself certainly carries overtones of the wisdom of the noble savage), yet the catalyzing effect of this vision on Llewellyn's later writings is undeniable. The claim inspired The Common Law Tradition, for in this, his last, book, Llewellyn substituted the "grand style" for "craft tradition" but otherwise continued to emphasize the ways in which craft techniques can free law from formalism and yet restrain the exercise of judicial caprice. (3) Finally, it was in The Cheyenne Way that Llewellyn first committed himself to a functionalist concept of the relation of law and society. There, he outlined a theory of the "law-jobs" that must be fulfilled in very society and he defined the "needs" that serve as criteria of whether the "law-jobs" are adequately fulfilled. ${ }^{81}$ The term "law-jobs" does not appear in The Common Law Tradition, but the later book was actuated by functionalist theories of social structure and the "inherent needs" that just decisions must fulfill. ${ }^{82}$ The linkage of justice and need-satisfaction originated in The Cheyenne Way, and it received its final treatment in the medical/biological imagery of The Common Law Tradition. ${ }^{83}$

Study of the Cheyennes thus provided Llewellyn with the concepts appropriate for a general theory of non-mechanical jurisprudence. ${ }^{84} \mathrm{~A}$ second issue remained, though, for Llewellyn also wanted to provide others with "right guidance" to the use of his antimechanical approach-to show how, and not merely that, law and justice could be brought into "daily working harmony." On this point, he encountered peculiar difficulty, for unlike the mechanists, he could not prescribe explicit rules but had instead to show how juristic method could govern the application, and occasional modifi-

${ }^{50}$ The theory was outlined in The Normative, supra note 53, and given a more expansive treatment in CheYenne Way, supra note 53. Professor Hoebel explains that the differences between the two works are attributable to the differences in the audiences they were intended for. Hoebel, supra note 41, at 739.

st See chapter 10 of CHEYENNE WAY, supra note 53.

\$ See, e.g., Common Law Tradition, supra note 1, at 211-12.

${ }^{83}$ See text and notes at notes 62-63 supra.

84 The importance of the Cheyenne trip to the development of Llewellyn's later jurisprudence was not lost on his biographer. See W. Twinisg, supra note 11, at 168. 
cation, of rules. It is here that Llewellyn's later jurisprudence is most subject to misunderstanding. Most writers on justice attempt to define the concept and to provide formulae for its achievement. Llewellyn did neither. "Justice," he argued, dissolves into banality when subjected to definition. And formulae for achieving it were, he believed, equally useless. ${ }^{85}$ Instead of these, Llewellyn offered examples-literally hundreds of cases in The Cheyenne Way and The Common Law Tradition-of how juristic method achieved justice in specific situations. The Cheyennes and the great judges served, in this respect, as exemplars of a method of doing justice, with Llewellyn writing as a "side-lines man" success. Llewellyn's approach to "right guidance" can be considered in many ways. In some respects, it resembled the preference of traditional moralists for teaching by example rather than by precept. ${ }^{87}$ It also bears some resemblance to modern philosophers', such as Wittgenstein's, emphasis on ostensive definition..$^{88}$ However, in whatever way his approach is conceived, it was uniquely suited to anti-formalism in jurisprudence. Prescriptive formulae would not do. Instead, given the intuitionist foundations of Llewellyn's concept of juristic method, a non-formal approach had to be found that could guide, by examples of past success, those who would apply the method in the future.

sommon Law Tradition, supra note 1, at 59-61; Low Philosophy, supra note 11.

* Common Law Tradition, supra note 1, at 265-66. It is perhaps interesting to speculate what "sidelines" role Llewellyn saw for himself. It is possible that he viewed himself as a "coach" who from the sidelines instructed the judge-players how they should go about deciding cases. In this sense Llewellyn may be thought of as a teacher of the juristic method. See note 65 supra. It is also plausible to view Llewellyn's "sidelines" role as not being that of coach but as that of "cheerleader." In this cheerleading role Llewellyn need not be viewed as somewhat presumptuously instructing judges about the proper mechanics of deciding cases, but instead may be viewed as limiting himself to advocating the use of juristic method. There are likely elements of both in Llewellyn's work, a pedagogic and an evangelical purpose, and he does not appear to have clearly distinguished the two. The discussion in text and notes at notes 100-115 infra treats Llewellyn's work as though he was teaching juristic method. See text and notes at notes 115-118 infra for a discussion of the implications of taking the view that Llewellyn intended only to advocate the use of juristic method.

${ }_{k 7}$ See, e.g., the opening sentence of bk. 1, ch. 1 of Fielding's Joseph Andrews: "It is a trite but true observation that examples work more forcibly on the mind than precepts: and if this be just in what is odious and blameable, it is more strongly so in what is amiable and praiseworthy."

It is both ironic and significant that Llewellyn extended Dean Langdell's case method to jurisprudence. Langdell had employed the method only to discover rules of law; Llewellyn captured its true spirit by treating it as a technique that could illustrate the way that past masters had succeeded at harmonizing law and justice.

* Wittgenstein, like Llewellyn, focused on learning how to use a term rather than on its formal definition. See L. Wittgenstein, Philosophical Invisstigations 3-6 (1953). Llewellyn remarked, "To say is one thing, to show is another . . . ." Common LAw Tradmion, supra note 1 , at 51 . 


\section{The Dual Questions of Legal Justification in Llewellyn's LATER WORK}

As discussed previously, Llewellyn during his early career was primarily interested in describing the system of mechanical jurisprudence. After his observations of the Cheyenne, however, he began to attempt more than description-he began to attempt to give "right guidance" to judges. He turned his attention, that is, to what judges ought to do. It was during this stage of his career that he became interested in answering the two questions of legal justification only implicitly posed in his early attacks on the system of mechanical jurisprudence: (1) How can order in legal decisionmaking be achieved? (2) How can the legal system produce just results?

In order to answer these questions, analytically Llewellyn first had to identify the conditions of order and justice, and he then had to suggest a means by which judges could fulfill these conditions and thereby achieve order and justice. Although Llewellyn did not in his works follow precisely this order of analysis, his achievement in suggesting a single (and perhaps the only) method that achieves both order and justice may best be understood if this order of analysis is followed.

\section{A. A Theory of Justice Based on Sociological Functionalism}

1. The Theory. Llewellyn's theory of justice gave expression to the ethical principles implicit in his sociological functionalism. Explicitly, Llewellyn assaulted philosophies of law based on eternal principles of justice ${ }^{89}$ Implicitly, though, Llewellyn retained a basic principle in his own thought: "heal the body politic";" but he then allowed for wide variation in its specific content. Two dimensions of Llewellyn's basic principle deserve special consideration: first, the priority that Llewellyn accorded to the satisfaction of basic needs; and second, the general approach he took to the distribution of surplus needs. Each merits individual attention, after which it will be possible to consider briefly the grounding of Llewellyn's theory of justice.

${ }^{89}$ See, for instance, Llewellyn's opening comments in The Low Philosophy of Law. "There is the High Philosophy and there is the low 'philosophy'. Each has its place and value. But when the High Philosophy gets to dealing with such matters as the Whitherness of the Whatever (say the problem of Ultimate Good or Ultimate Teleology) or even of Whatever's Whetherness (say Deontology, Cosmology, or the Metaphysics of Knowledge and Truth) most of it gets not only beyond law but beyond most of us." See The Low Philosophy of Law, supra note 12 , at 1 .

${ }^{20}$ See text and notes at notes 64-65 supra. 
In one sense, Llewellyn most certainly did not dispense with a fixed principle of justice. He granted that "bare-bones" needs "must be met" before socially-created ones can be considered.91 The content of "bare-bones needs" is not entirely certain; but one can at least be sure that the term excludes those factors that are culturally contingent and includes the biological necessities of life..$^{22}$ Furthermore, Llewellyn's insistence that these basic needs "be met" before all other needs reveals a principle of serialization implicit in his theory of justice. Basic needs must be satisfied before judicial attention can justifiably be turned to others; hence basic need satisfaction is more important than surplus need satisfaction.

Llewellyn also left the content of "surplus needs" largely undefined. Here, he recognized that needs vary according to differences in culture and that a theory of justice grounded in functionalism therefore could not identify in advance the needs that must be satisfied in order for it to be said that "justice" has been done..$^{93}$ Instead, he remarked only on the distributive characteristics of a just decision-that it must create a "solution for the Entirety." like so many others in Llewellyn's lexicon, is frustratingly vague. It does not allow the reader to ascertain Llewellyn's choice between aggregative or egalitarian ${ }^{95}$ standards of distribution, for both can be said to offer "solutions for the Entirety." However, it does exclude distributive remedies that benefit one class or caste while not promoting aggregate welfare for a society. In this limited sense, even

" Good in Law, supra note 45, at 253, reprinted in JURISPRUDENCE, supra note 9, at 167, 200.

32 Llewellyn once remarked that "when basic needs which have been forgotten raise their heads suddenly, men who have forgotten those needs are likely in turn to lose their heads, and panic lightly sacrifices high goals to the moment." Good in Law, supra note 45, at 253, reprinted in JURISPRUDENCE, supra note 9 , at 167, 200.

93 Thus Llewellyn characterized this as a "questing aspect" of justice whose content varies according to "cultural configurations." See CHEYENNE WAY, supra note 53, at 292. Llewellyn's reference to "cultural configurations" is significant since it indicates Ruth Benedict's influence on his approach to surplus needs. The influence is hardly surprising since Adamson Hoebel, the co-author of The Cheyenne Way, had been a student of Benedict before beginning his work with Llewellyn. See Hoebel, supra note 41, at 735. For Benedict's concept of "cultural configuration," see R. Benedict, Patterns of Culture 55-56, 246-50 (1934).

" CheYenne Way, supra note 53, at 309.

s In aggregative distribution, need-satisfactions would be distributed in such a way as to maximize the total number of further satisfactions. Thus an aggregative principle of distribution would justify inequalities in the distribution of need-satisfactions as long as these were likely to produce a greater number of such satisfaction than would any other scheme of distribution. By contrast, egalitarian distribution would distribute such satisfactions "equally" among members of a society. At least two kinds of equality are conceivable: equal distribution to each person, or distribution that is proportionally equal to the intensity of personal desire for such satisfactions. For a discussion of the tension between the two principles of distribution, see J. RAwLs, A THEORY OF JusTice 60-118 (1971). 
the vague requirement of a "solution for the Entirety" places some constraints on the "just" distribution of surplus needs. Thus, Llewellyn's jurisprudence cannot be said to be entirely without content. Normative principles underlie Llewellyn's writings.

One final issue deserves consideration here. How, one wants to know, would Llewellyn have justified his basic claim concerning justice, that is, his linkage of justice with need-satisfaction? Without such a justification, Llewellyn may be said to have offered "guidance" to judges, but not necessarily the "right guidance" he claimed to have provided. Unfortunately, Llewellyn did not confront this question directly. At most, one can infer a rudimentary teleological justification that is implicit in his writings. Society, Llewellyn believed, is organized in order to fulfill long-term individual interests-first, an interest in survival; and second, a "questing" interest that arises out of the surplus remaining after survival has been guaranteed. ${ }^{96}$ This proposition is merely descriptive: it states what is, not what ought to be, valued. Yet Llewellyn, following Dewey, apparently believed that these facts concerning human values were themselves valuable. ${ }^{97}$ Possibly there is much that is metaethically questionable about such a transition from the valued to the valuable. But even though Llewellyn must be held accountable for the difficulties that arise from this, he should perhaps not be pressed too hard on the point. The argument is, after all, Dewey's ${ }^{98}$ (and, indirectly, Mill's ${ }^{99}$ ); and though Llewellyn may have implicitly accepted it, it was they who worked out its implications most fully. Thus it is best simply to note, and not to criticize, the metaethical foundations of Llewellyn's work.

2. Juristic Method. Juristic method is the technique that Llewellyn proferred for defining and implementing his (virtually contentless) principle of justice. In an important passage in The Cheyenne Way, Llewellyn distinguished between mere "legal method," which he conceived to be value-neutral, and "juristic method," which he described as the "technique . . . of Justice."100

${ }^{96}$ Good in Law, supra note 45 , at 250,253 , reprinted in JURISPRUDENCE, supra note 9 , at 167, 200.

${ }^{87}$ See Legal Science, supra note 42, at 23 n.27. Dewey made a similar transition. See J. DEWEY, supra note 44 , at 266.

- ${ }^{8}$ J. DEwEY, supra note 44, at 266.

${ }^{9}$ Mill, Utilitarianism (1832), in The Philosophy of John Stuart Mild 321, 362-70 (M. Cohen ed. 1961).

${ }^{100}$ Legal method may be skillful, it may be ingenious, splendid of technique, and varied; but where its purpose is to serve a litigant or client only, and not Justice, it is only legal. Juristic method is the problem and the technique of solution, for the Entirety, and the problem of keeping the machinery of the law abreast of the needs of the Entirety.

Cheyenne WaY, supra note 53 , at 309. 
Juristic method, Llewellyn felt, gives appropriate ethical expression to the needs found in a particular society at a particular time. Where Llewellyn refused to define the needs that require attention for the sake of justice (and where he refused to do more than state that "basic needs" are to be given priority over "surplus needs"), he entrusted to juristic method the task of arranging needs according to a "solution for the Entirety."

As seen, juristic method is meant to accomplish this task in two stages. First, it offers a diagnosis of "the significant problems involved" in a case. Second, it offers a prescription of "the appropriate line of treatment" to be followed.101 For this method to function properly, and achieve just results, it must provide unambiguous guidance at each stage; that is to say, it must identify the needs involved in a case that "justice" requires to be satisfied, and it must then point toward a single rule appropriate for fulfilling these needs. Does juristic method succeed at this? Perhaps it does, but no definite answer can be given to the question as posed. First, it is best to examine the method as Llewellyn, by example, taught it. Considered in this light, juristic method must be considered something of a disappointment. The method, at least as Llewellyn taught it, does not appear to offer the unambiguous guidance that one would like to obtain from it. There remains the possibility that Llewellyn's described method was incomplete, that juristic method, as actually used by judges, contains features that Llewellyn's description did not. However, the method, as Llewellyn taught it, allows for ambiguities in the guidance provided to judges, and these ambiguities should be examined.

Consider first the extent to which Llewellyn's teaching helps judges clearly identify the needs relevant to a just decision. Perhaps it should first be made clear what Llewellyn was not advocating. Contrary to the claims of some of his later interpreters, ${ }^{102}$ Llewellyn did not believe that a survey of a society's practices was sufficient to identify its surplus needs. On the contrary, Llewellyn acknowledged that common practices could on occasion, disserve, rather than serve, such a community. Consequently, in The Common Law Tradition, Llewellyn contrasted "the inherent needs" of a community with its empirically regular practices. ${ }^{103}$ In this respect, he was following Cardozo who had remarked, in his lectures on the

10 Common Law Tradition, supra note 1 , at 450.

102 See, e.g., Rohan, The Common Law Tradition: Situation Sense, Subjectivism or JustResult Jurisprudence? 32 FordhaM L. REv. 51 (1963).

${ }^{105}$ See, e.g., Llewellyn's discussion of Equitable Trust Co. v. Keene, 232 N.Y. 290, 133 N.E. 894 (1921), in Common Law Tradition, supra note 1, at 211-12. 
judicial process, that "when social needs demand one settlement rather than another, there are times when we must . . . sacrifice custom in pursuit of other and larger ends."104 But, ironically, Llewellyn proved to be more of a purist in his juxtaposition of custom and need than Cardozo, as is illustrated by his criticism of Cardozo's holding in Whiting v. Hudson Trust Co. ${ }^{105}$ There, Cardozo had relied on the regular custom of New York banks in holding a bank not to be liable to the beneficiary of a trust when the bank had, pursuant to banking custom, knowingly permitted the trustee to register the account in his, rather than the trust's name. ${ }^{106}$ Llewellyn, by contrast, championed the "needs" of a larger community - of beneficiaries, for instance, or of potential transferors-over the regular practices of the banks themselves. ${ }^{107} \mathrm{His}$ criticism of Cardozo on this point reveals the core of his concept of "inherent need": The needs that determine just results were not, according to Llewellyn, discernible in the regular customs of a society but were instead to be discovered in the underlying expectations ("basic cultural norms," one might say) that a society's members bring to their daily tasks. ${ }^{108}$ Llewellyn's application of the fiduciary principle to Whiting illustrates the non-customary character of "inherent need"; for Llewellyn, lay expectation of fiduciary principles was of greater importance to justice than was the professional bankers' custom of dispensing with the principle in this situation. Thus, to the extent that "inherent needs" diverged from regular practice, Llewellyn consistenly turned to the former in preference to the latter.

${ }^{10}$ B. CARDozo, supra note 23, at 65. It should also be noted that in MacPherson v. Buick Motor Co., 217 N.Y. 382, 391, 111 N.E. 1050, 1053 (1916), Judge Cardozo had appealed to the "needs of life in a developing civilization" as a justification. For the functionalist rationale of this discussion, see G. CASPER, JURISTISChER REALISMUS UND POLITISCHE THEORIE IM AMERIKANISCHEN RECHTSDENKEN 27-42 (1967).

${ }^{105} 234$ N.Y. 394,138 N.E. 33 (1923).

${ }^{106} \mathrm{Id}$.

${ }^{107}$ See Common Law Tradition, supra note 1, at 439, where Llewellyn discusses the tension between the banking practices on which Cardozo relied and what Llewellyn called, in the context of his discussion of Whiting, the "needs of the community." Llewellyn recognized the difficulty of this task. "[I]t is a good man who at present writing can lay down the difference between 'yielding to public clamor or political power' on the one hand, and 'feeling and serving the demands of the times for justice' on the other." See Newer Jurisprudence, supra note 40, at 588, reprinted in JURISPRUDENCE, supra note 9, at 128, 136.

${ }^{108}$ It is ironic that Llewellyn wished to push even farther than Cardozo in the application of the fiduciary principle since it was Cardozo who expressed the principle in its modern form in Meinhard v. Salmon, 249 N.Y. 458, 164 N.E. 545 (1928). It is appropriate to think of Cardozo as championing in this decision a "basic cultural norm" in preference to the morals of the marketplace that would normally prevail among joint venturers. For a theoretical formulation of the foundations of role-based ethical rules, see D. EMMET, RULES, RoLEs, AND ReLATIONs (1966), 
If these needs are not identified by simply looking to custom or practice, how, then, are these needs identified in the juristic method as Llewellyn taught it? A defender of Llewellyn's strategy of guidance might argue that these needs need not be identified in the abstract at all-that we may rely instead on the judge's "situation sense" 109 to intuit the needs-and that Llewellyn's teaching of juristic method by example ${ }^{110}$ goes as far as any system of guidance can in inculcating sound "situation sense." But such an argument overlooks the extent to which verbal definition can at least narrow the parameters of "inherent need." Two examples should help to illustrate the narrowing process that remains to be done. First, what is the criterion of an "inherent need"? Lewellyn clearly did not believe this to be a metaphysical concept, for he thought that the future course of a society's development would reveal whether or not a need was "inherent.""11 But, since judges are not blessed with foresight, this futurism does not offer them a criterion for present identification of needs. Instead, a generalization from past experience might help to develop such a criterion. Unfortunately, Llewellyn never attempted such a generalization. Second, as another example of missed possibilities for narrowing, what are the communal boundaries of need? In a warranty case, for instance, is the relevant community defined by manufacturers alone, by the world of manufacturers and direct consumers of the product, or by the national community in which these relations arise? A more precise definition than Llewellyn's of communal boundaries is both conceivable and desirable, for to trust to a judge's "situation sense" is to raise the possibility that different judges will intuit the boundaries of a similar situation in different ways. In this respect, Llewellyn's proferred strategy of guidance makes possible mutually inconsistent "diagnoses" of a situation. On even the most fundamental points-on the identification of which need is "inherent," for example, or on one definition of the communal boundaries of need-his strategy leaves room for significant judicial disagreement. As Llewellyn taught it, then, juristic method cannot be said to be capable of offering completely unambiguous identification of ethically relevant needs. Granted that it at least points a court in the correct direction, toward "basic cultural norms," it nevertheless offers judges less than perfectly clear guidance for discerning what these

\footnotetext{
109 See note 39 supra.

116 See text and notes at notes 85-88 supra.

"II Thus Llewellyn praised Cardozo's decision in MacPherson as one that could "fit the modern need" and also "guide the future." Common Law TradrTion, supra note 1, at 431.
} 
norms are in a given situation.

Llewellyn's approach to "prescription" also presented ambiguities. Two factors make it difficult to discern a clear method of prescription that Llewellyn suggested. First, Llewellyn tended to blur his own dividing line between diagnosis and prescription, tended to write as though correct diagnosis of "inherent needs" would automatically yield clear-cut prescriptions of appropriate "needserving" rules. ${ }^{112}$ Llewellyn's celebrated quotation of the passage from Levin Goldschmidt's writings, where Goldschmidt suggested that "right law" is "indwelling in the very circumstances of life" furthered this tendency on Llewellyn's part to blur the distinction. Yet, it should not be forgotten that it was Llewellyn who set forth the distinction between diagnosis and prescription, ${ }^{114}$ and his blurring of the distinction makes his guidance to judges ambiguous. Second, even on those occasions when Llewellyn observed the distinction, he ignored the many complexities that separate diagnosis and prescription. Even in the simplest situation, there is of course a logical distinction between perception of a need and decision on a course of action that will satisfy it. The gap between diagnosis and prescription must widen when there are multiple, and possibly irreconcilable, needs implicated in a case. This is, in fact, where the distinction is most useful, for it acknowledges the possibility that any one prescription may not equally satisfy all relevant needs. Unfortunately, Llewellyn seems also to have overlooked this difficulty and to have trusted to his general strategy of guidance to enable judges to make the transition from complex diagnosis to prescription. Once again, though, it must be reiterated that within the context of Llewellyn's description of juristic method, a narrowing process is possible: even if Llewellyn believed that intuition had to be entrusted with ultimate authority in the formulation of prescriptions, he could at least have drawn generalizations from the manner in which the great judges who have used the juristic method had balanced competing needs against one another in creating rules

"12 See, for example, Llewellyn's discussion of Fairweather v. Wiley's, Inc., 183 Kan. 579, 331 P.2d 330 (1958), where he stated that, in a tort case, the "immanent law as to where to place the risk" can be consistent with past experience and so be dispositive. Common LAw Tradition, supra note 1, at 271. Also see Llewellyn's remarks, following a series of Pennsylvania divorce cases, that "We have seen again and again the need . . . for the court to be informed about the scope and nature of the significant type-problem-situation, of how inside that situation life works out, of the implicit values and standards which the situation holds to channel conduct and to guide resolution of conflicts within itself-in a word, about its Goldschmidt's immanent law." Id. at 308.

113 Id. at 122.

IIs Id. at 450 . 
that achieved just results. This he did not do, and his teaching of juristic method was thereby impoverished.

Llewellyn's teaching of juristic method suffered, then, from a serious problem of vagueness. Judges utilizing his teachings could neither identify with certainty the needs that are relevant for the formulation of rules, nor could they determine how they should balance competing needs and come up with an appropriate rule. Juristic method therefore promised a technique of justice appropriate for social functionalism-on this point its theoretical role is clear. But, given Llewellyn's minimal specification of the method, one may doubt whether the method, as taught, could perform in a way that could bear the heavy burden placed on it-the giving of content to a virtually contentless principle of justice, and the formulation of courses of action that will achieve justice. In this respect, at least, Llewellyn's juristic method is a disappointment.

These criticisms, it must be emphasized, only concern juristic method as Llewellyn taught it. As a "side-lines man,"115 his intention was at least in part to formulate "communicable working principles" that describe the feats of technique performed by great judges and so to help raise the level of performance of the entire judiciary. ${ }^{116}$ Given Llewellyn's extensive claims for the efficacy of juristic method and the grand style, it is conceivable that he would have admitted failure at his task of advocacy before he would have admitted to any failings on the part of juristic method. ${ }^{117}$ Thus he might well have granted the criticisms that have been stated but then have insisted that the difficulties were of his making, not the method's, and that the method in operation could achieve right results. ${ }^{118}$

${ }^{115}$ See note 86 supra.

I1 See Common Law Tradition, supra note 1 at 266 , 378-79

117 If now, you ask me what guarantee I can offer that my own faith about the Good in this institution of the law is better than another's-what does Reason show me to warrant this particular faith of mine against mistake-I have no answer. Under the common law tradition, be a man judge, citizen, or scholar, They That Come After have as their office to correct him. When the machinery of work is healthy, and formalism does not hide on-going reason, They That Come After do their office of correction.

Meantime, a clear faith is a fighting faith. And as for guaranty, I can but rest on an ancient and magnificent summing-up: credo ut intelligam. Which I prefer to render: as a result of my faith, I grasp it with my mind.

Good in Law, supra note 45, at 1264-65, reprinted in JURISPRUDENCE, supra note 9, at 167, 212,

$11 \times$ "And the certainty in question is that certainty after the event which makes ordinary men and lawyers recognize as soon as they see the result that however hard it has been to reach, it is the right result." Common Law Tradition, supra note 1, at 185-86 (emphasis added). 


\section{B. The Conditions of Legal Order}

Juristic method implements, albeit perhaps imperfectly, Llewellyn's approach to justice. In addition to this, it is also the key to his solution of the problem of legal order. This latter claim can best be understood by examining the conditions that any judicial approach must fulfill if it is to resolve the problem of legal order. As will be seen, juristic method satisfies these conditions and so offers a key to the problem's resolution.

It may be inferred from Llewellyn's writings that he thought that two conditions are essential to the operation of a system of predictable (orderly) legal decision-making. First, Llewellyn believed that there must be an unambiguous judicial approach to deciding cases-an approach that can produce a single result each time an essentially similar set of facts is presented. This may be called the "primary" condition of order. Second, Llewellyn argued, in order to achieve predictable decision-making over time, it is also necessary that there be a congruence between the judicial approach and the actual "needs" or problems of a society. This may be called the "secondary" or "long run" condition of order.

That Llewellyn thought the "primary" condition to be a prerequisite to accomplishment of orderly decision-making may be inferred from his early writings describing mechanical jurisprudence. Llewellyn there argued that the "leeways of precedent" inherent in the hierarchical system of rules of mechanical jurisprudence made it impossible, in many cases, for judges to deduce a single "correct" result. This failure of guidance from the rules made it all but inevitable that judges would decide many cases according to idiosyncratic standards, and therefore that unpredictability would result. ${ }^{119}$ Implicit in this early criticism is the notion that complete predictability can be achieved only if the approach utilized can yield a single result each time like facts are presented. The approach used must enable a judge to identify one result that is proper in a given case. Unless the "leeways of precedent" could be eliminated from mechanical jurisprudence, this rule-based system could not meet the primary condition of order.

Llewellyn also believed that a second condition is necessary if legal order is to be maintained over a period of time. This condition, the secondary or long run condition of order, may not appear as intuitively obvious as the primary condition. To understand why Llewellyn added this second condition, it is necessary to return to

119 See text and notes at notes 24-26 supra. 
his functionalist conception of the role of law in society. It is obvious that legal order can be achieved only if all judges adhere to the same approach. Even a method of decision that is capable of producing completely non-ambiguous results cannot produce certainty if some judges fail to decide cases according to the method. Adherence by judges to a single approach over time should result if the secondary condition of order is satisfied. This condition is the congruence between judicial standards for resolving cases and the needs of society. When this congruence is achieved, according to Llewellyn, there will be long-term predictability of result, for there will be no societal pressure on judges to abandon their approach in favor of another.

Why is this congruence essential to long-term predictability? The reason may be found in the expectation, which Llewellyn attributed to laymen ${ }^{120}$ and judges ${ }^{121}$ alike, that law will play a needserving integrative function in society. Law, Llewellyn claimed, is the "one centralizing, organizing, whole-serving institution" found in society, ${ }^{122}$ and both judges and the general populace expect the law to fulfill this need of society. ${ }^{123}$ Because both laymen and judges expect the law to perform this function, judges who do not resolve cases in this need-serving manner will become subject to internal pressure ${ }^{124}$-and to pressure from society and other judges-to do so. Judges are inevitably drawn back to the expected function of the law. ${ }^{125}$ The secondary condition, framed as it is in a basic expectation of the function of the law, serves as a bedrock in determining

${ }^{120}$ See Law \& Social Sciences, supra note 54, at 1291-93, reprinted in JuRISPRUDENCE, supra note 9, at $352,357-58$, where Llewellyn states that the "mere layman" has a "surer intuition" of the need-serving, socially integrative role of law than do social scientists; and Llewellyn, American Common Law Tradition and American Democracy, 1 J. LEg. \& Poz. Soc. 14, 38 (1942), reprinted in JURISPRUDENCE, supra note 9, at 282, 308, where Llewellyn refers to the "law-consumer's" "yearning" that the law be "right."

121 Llewellyn made repeated references to the desires of judges to do justice, to serve the needs of society. For example, Llewellyn once observed that judges' "personal judgment[s] may be informed always with a drive for rightness." Law \& Social Sciences, supra note 54, at 1297 , reprinted in JURISPRUDENCE, supra note 9, at 352, 362 (emphasis in original). On another occasion, Llewellyn asserted that judges, along with other law practitioners, recog. nize that theirs is an institution with "service to perform." See Address at the Dedicatory Celebrations, The University of Chicago Law School, April 30, 1960, reprinted in JURISPRUDENCE, supra note 9, at 375, 391-92.

${ }^{12}$ Law and Leadership, supra note 60, at 56.

123 See notes 120-121 supra.

${ }^{124}$ Llewellyn frequently referred to the "felt sense of duty" of judges. See, e.g., CommoN Law Tradition, supra note 1 , at 59.

${ }^{125}$ Cf. Llewellyn, The Modern Approach to Counselling and Advocacy-Especially in Commercial Transactions, 46 Colum. L. Rev. 167, 180 (1946), reprinted in JuRISPRudence, supra note 9, at 323, 338 (emphasis added): "While the courts have and know a duty to the Law, their office forces on them also, and they have and know and labor to live up to, a duty to Justice, to decency and fairness of result." 
the possibility of predictability. Judges may act contrary to expectations for a relatively short period of time-thus the satisfaction of the primary condition may offer short-term predictability of result. Over the long run, however, judges must cope with the pressures generated by these expectations - thus the requirement that judicial approaches be attuned to social needs if there is to be long-term predictability of result. All other approaches may endure for a while, but they will, according to Llewellyn, break down as some judges respond to the expectations of a broader-based judicial standard. ${ }^{126}$ Only one approach can endure, an approach that is attuned from the outset to the integrative function of the law. ${ }^{127}$

Perhaps it would be helpful to provide some examples that illustrate the operation of the secondary condition of congruence between a shared judicial standard and the satisfaction of social needs. The examples are not Llewellyn's, but they should clarify his claim that, because there exist expectations that law will play an integrative, need-serving role, only those standards of decisionmaking that are oriented toward social integration can offer predictability of result. Consider first an approach that is patently capricious-a judicial preference for blondes rather than brunettes, for instance. This standard ("blondeness") is not ambiguous, and thus allows for predictable decision-making so long as judges adhere to it. However, this standard would likely soon come into conflict with lay and judicial expectations that the law should perform a broader role than "blonde-serving." Because of this, judges might soon try to promote other goals within the context of the blonde-based rules-perhaps by covertly creating artificial ambiguity or by simple covert refusals to decide cases according to the blondeness standard. If they did deviate from the blondeness standard, the standard could no longer produce predictable results, for it would merely camouflage the judicial attitudes covertly promoted.

What, though, if judges agreed on a less capricious standard of value-on the protection of private property, for instance, rather than on the protection of blondes? Here, there is greater likelihood of long-term judicial agreement (and thus predictability of result)

${ }^{123}$ Against any spiderwebby, clumsy, or stingray conclusion, of course, has stood the common law tradition of revising the premise when a conclusion proves too tough to take .... [W] hen courts have repeatedly slid away from a principle, common law experience shows that the fauit may frequently (not always) be discovered less in the courts than in a "principle" which has not been making sense.

Common Law Tradition, supra note 1, at 349-50.

${ }^{127}$ It is by performing an integrative function of the law that a court serves the needs of society. See text and notes at notes 59-68 supra. 
because this standard commands broader public acceptance. However, unless the judges using this standard are operating in a jurisdiction populated by libertarians who acknowledge the legitimacy of coercive state action only for the purposes of protecting property, it is also predictable that even this standard would conflict with the prospects for social integration and thus with the expectation of judges and laymen. At this point, some judges might either break with the property standard or else might subvert it from within by making rules ostensibly based on the defense of private property but in fact based on a private concept of the means to social integration. Thus, rules under this standard would also not promote long-term predictability of result.

By contrast, a standard geared to congruence with social needs would not generate pressures for judicial deviations from the announced standard. The standards in the previous examples offered predictability only so long as judges remained indifferent to serving social needs. According to Llewellyn, there will come a time when expectations force at least some judicial responsiveness to needs, and these deviations from the announced standard of caseresolution will result in unpredictability in decision-making. Only an approach that explicitly makes the satisfaction of social needs its goal will not provoke defection which undermines long-term predictability of result.

C. The Convergence of Order and Justice: A Key to the Unity of Llewellyn's Jurisprudence

The theories of order and justice converge on a single point-the fulfillment of "inherent social need"-and on a technique for achieving this-juristic method. The key to Llewellyn's jurisprudence is to be found in this point of convergence, for there is a sense, as yet undefined, in which juristic method performs a double duty in promoting justice and legal order. This section will describe more carefully that point of convergence. The section begins with a basic proposition about the relation of justice and legal order, and it then varies the proposition in order to define more fully the way in which they converge. This proposition states that if juristic method (the method of implementing justice ${ }^{128}$ ) is employed, then there can be long-term predictability of result in judicial decision-making. Variations will follow; but even without further consideration, the proposition, as stated in its simplest form, indi-

12x See text and notes at notes 100-115 supra. 
cates that, for Llewellyn, the quest for justice coincides with the achievement of legal order.

What variations can be worked on this proposition? Three will be examined. First, the proposition can be considered solely in terms of short-terms predictability of result. In this case, juristic method will not necessarily prove itself superior to all its competitors. However, when attention is turned to the long run, juristic method will seem more attractive. At the very least, its adoption can promote considerable predictablity of result-thus the second variation on the proposition. And third, if properly employed, juristic method could offer complete predictability; and it could, in this way, wholly solve the twin problems of order and justice that were posed at the outset. The second point, it must be emphasized, was Llewellyn's; the third only impliedly his. However, the third is important as a means of defining the status of the second, so both deserve careful consideration.

Consider first the problem of short-term predictability. Here, only definiteness is required, for short-term predictablility depends only on judicial employment of unambiguous rules. ${ }^{129}$ Llewellyn appears to have believed that juristic method was more definite than mechanical jurisprudence, which is flawed by the existence of "leeways of precedent."130 But he did not claim-and the earlier criticisms of the vagueness inherent in juristic method should make clear why he could not-that the method inevitably identified a single outcome of a particular case. ${ }^{131}$ Other methods might conceivably be clearer, if only because they were simpler. In the short-term, then, juristic method, as described by Llewellyn, may well offer less predictability of result than other methods.

However, as the examples of blonde- and property-based rules demonstrate, when rules fail to promote social integration, then judges are exposed to serious pressures to covertly use them to nevertheless do just this. An example from The Common Law Tradition further illustrates this point. In his discussion of the "principle'

129 See text and notes at notes 119-127 supra.

130 The inference is not certain because Llewellyn did not compare the methods with one another on this point. However, an indirect comparison helps to indicate his opinion. Llewellyn's employment of the word "result" in two different passages indicates that he believed $\mathrm{craft} / \mathrm{method}$ yields greater predictability of result than does mechanical jurisprudence. Of the latter approach, Llewellyn stated that it produces an "unreal certainty, [a] certainty unattained in result." Realism about Realism, supra note 9 , at 1253 , reprinted in JURISPRUDENCE, supra note 9, at 71. Of his own approach, though, Llewellyn claimed that it could produce "reasonable reckonability of result." COMMON LAW Tradition, supra note 1, at 17-18.

${ }^{131}$ See text and notes at notes $110-115$ supra. 
that no 'offer' can be accepted by one who did not know of it first," Llewellyn tried to show how this rule, widely accepted by legal scholars of the late nineteenth century, nonetheless proved to be at such variance with "folk moral judgments" that it was slowly subverted from within by the creation of many exceptions to the rule. ${ }^{132}$ Given Llewellyn's linkage of justice with need-satisfaction, it can be said that he saw those "subverting" judges as responding covertly to the expectations of justice. But a response of this kind creates a basic tension between what Llewellyn called the "precedent phase" of justice and "the dynamic readjustment of a going system to just what needs to be done." 133 Thus, in a system where rules are not framed in terms of social need, justice will often be achieved at the cost of order-and there will always be sufficient judicial responsiveness to social needs that legal order will not be attainable.

Juristic method resolves this tension and so offers at least approximate predictability of result over the long run. The proof for this point can be found in the examples, cited previously, of how alternative standards provoke judicial defection while a standard congruent with social need (as juristic method is by definition) does not. Llewellyn never offered a formal proof of this kind, but his writings point in this direction. ${ }^{134}$ Furthermore, Llewellyn's own statements serve as impressive evidence of his own intentions, for they indicate that the resolution of the tension between law and justice was the focal point of his later jurisprudence. His recollection of the Cheyennes was expressed in terms of this theme. "The law of the Cheyenne Indians made clear to me what I had never before dreamed: to wit, that law and justice had no need at all to be in conflict or even in too much tension, but could instead represent a daily working harmony." 135 And, in 1942, just after completing his work on the Cheyennes, Llewellyn then applied the same insight to American appellate courts: "Serious opposition of Law and Felt Justice is not only unfortunate, but is in good part unnecessary, in our legal system, granted the prevalence of a sound case law style." ${ }^{136}$ For Llewellyn, then, this was the key to a unified jurisprud-

132 See Common Law Tradition, supra note 1 , at 351-52.

133 Id. at 513.

134 See, e.g., Common Law Tradition, supra note 1, at 350-51 (discussed in text at note 132 supra); American Common Law Tradition and American Democracy, supra note 120, at 35 (1942), reprinted in JURISPRUDENCE, supra note 9, at 282, 304 (arguing that the non-need serving formalism of the late nineteenth and early twentieth centuries was forced to yield because of the "dire . . . conflict" of this legal method with "the needs voiced by legislatures").

${ }^{135}$ Common Law Tradition, supra note 1, at 513.

136 American Common Law Tradition and American Democracy, supra note 120, at 38; reprinted in JURISPRUDENCE, supra at note 9 , at 282, 308. 
ence: if judges adopt a method attuned to "inherent social need," then they can also enhance considerably the predictability of their own decision-making.

This is the second version of the basic proposition, and it states Llewellyn's position. Llewellyn, it should be added, promised no more than this. He argued only that the adoption of juristic method would bring about "reasonable reckonability of result"; he did not claim that it would bring about complete predictability. ${ }^{137}$ In this respect, Llewellyn was bowing to obvious facts about the everyday world: given human frailties and fallibility, it is unlikely that any method can be applied perfectly, so it is best to claim only reasonable, and not complete, predictability of result. However, the modesty of Llewellyn's claim for juristic method leaves undefined an important issue concerning the status of juristic method. Could some other method offer even greater predictability of result over the long run even though it did not bring about just results? Or, on the other hand, did Llewellyn believe, even silently, that to the extent that justice is achieved (which juristic method is best suited to do), then to that extent only can long-term predictability of result also be achieved? If Llewellyn had held to the former view, then he had, in effect, established a contingent relation between the achievement of justice and order; if to the latter view, then he believed that their relationship was a necessary one. That is, he may have felt no more than that by achieving justice it is also possible to achieve order; or he could have gone farther and argued that the long-term achievement of order is possible only through the achievement of justice. This is the third variation on the basic proposition. There are good reasons to believe that the latter was closer to his intentions.

Reiteration of a basic point should demonstrate why the latter view may fairly be attributed to Llewellyn. As was stated earlier, "inherent need" is the axial concept of Llewellyn's later jurisprudence. Fulfillment of inherent need satisfies the conditions of justice-this is true by definition in Llewellyn's jurisprudence. Furthermore, over a long period of time, fulfillment of inherent need also satisfies the conditions of legal order-this is not true by definition but it instead follows from Llewellyn's functionalist premise as to the expected integrative role of law in society. Given Llewellyn's approach, justice can never be achieved without satisfying "inherent need." Legal order can, however, be sustained for a short time by a variety of factors other than the satisfaction of such needs.

137 Common Law Tradition, supra note 1, at 17-18. 
In the long run, though, according to Llewellyn's argument, the factor that identifies the justness of a decision is also the one that makes possible sustained legal order. In this basic sense, the relation is a necessary one, for without the focus on justice there could be no long-term predictability of result within a legal system.

This point should indicate the special status of juristic method, for there is no reason in theory why juristic method cannot lead to complete, not merely reasonable, reckonability of result. The basis for juristic method's shortcomings in this respect are to be found in human frailties of one kind or another: some judges might reach decisions on incorrect information, others might misdiagnose a situation, still others might seek to promote private interests. ${ }^{138}$ In everyday life, all of these circumstances can arise-thus the qualification, "reasonable reckonability of result." However, there is no reason in theory why judges should not have complete information, should not apply juristic method infallibly, and so forth. If they did, then juristic method would invariably bring about just results. Its complete achievment of justice would also bring about complete predictability of result, for the factor that juristic method focuses on in achieving justice ("inherent need") is also the factor that makes possible long-term order in a legal system. Unerring judicial attention to "inherent need" will (in theory) necessarily solve completely the problems of justice and order.

This is, of course, only a theoretical point. Yet it does serve to underscore the necessary relation, implicit in Llewellyn's later work, between the achievement of justice and legal order. Thus, the third variation on the basic proposition: if juristic method is employed properly, then there can be completely predictable decision-making by judges. This version of the proposition helps to explain the status of the second variation. The convergence of approximate order and the use of the juristic method stated in the second variation was not, in fact, coincidental, even though the second allowed for only "reasonable [not complete] reckonability of result." Instead, the second variation also reflected the necessary relation between the achievement of justice and legal order. The second merely allowed for human frailties, but it otherwise stated the relationship more

${ }^{139}$ Even in a craft tradition, there remains the possibility that a judge could manipulate rules for private purposes. However, the craft tradition makes this judicial dereliction of duty more difficult to hide than under mechanical jurisprudence. In a formal system, the leeways of precedent can, if discreetly handled, shield a judge from public scrutiny. In a craft tradition, though, in which rules are framed explicitly in terms of public policy and where it is expected that judges will promote social integration, judges would have greater difficulty hiding their manipulation of legal rules to suit their own purposes. 
clearly defined in the third version. Human frailty is such that juristic method will never be entirely successful at its task. Nevertheless, for Llewellyn, juristic method is the necessary condition for long-term achievement of legal order in society. In Llewellyn's later works, then, ius is the key to orderly law.

\section{Conclusion}

In sum, Llewellyn suggested that there is a necessary relation between the achievement of justice and the establishment of longterm predictablity of result in a legal system. He thus resolved jointly the difficulties he had first detected in mechanical jurisprudence. Furthermore, a unity can be discerned in Llewellyn's writings on the philosophy of law. In his early work, Llewellyn exposed the leeways of precedent that make unlikely the achievement of legal order and justice. In his later work, Llewellyn forged the issues of order and justice together and suggested that to the extent that judges adhere to a standard based on "inherent need" there will be predictable results. Llewellyn's later argument therefore resolved in a comprehensive fashion the two problems of justification that he had initially detected during his attacks on mechanical jurisprudence.

William C. Heffernan 